TITLE:

\title{
STUDIES ON THE CIRRIPEDIA ACROTHORACICA - II. INTERNAL ANATOMY OF THE FEMALE OF BERNDTIA PURPUREA UTINOMI-
}

\author{
$\operatorname{AUTHOR}(\mathrm{S})$ : \\ Utinomi, Huzio
}

\section{CITATION:}

Utinomi, Huzio. STUDIES ON THE CIRRIPEDIA ACROTHORACICA -II. INTERNAL ANATOMY OF THE FEMALE OF BERNDTIA PURPUREA UTINOMI-. PUBLICATIONS OF THE SETO MARINE BIOLOGICAL LABORATORY 1960, 8(2): 223-279

ISSUE DATE:

1960-12-20

URL:

http://hdl.handle.net/2433/174653

RIGHT: 


\title{
STUDIES ON THE CIRRIPEDIA ACROTHORACICA \\ II. INTERNAL ANATOMY OF THE FEMALE OF BERNDTIA PURPUREA UTINOMI ${ }^{13}$
}

\author{
HUZIo UTINOMI
}

Seto Marine Biological Laboratory, Sirahama

With Plates XXXI-XXXIII and 36 Text-figures

\section{CONTENTS}

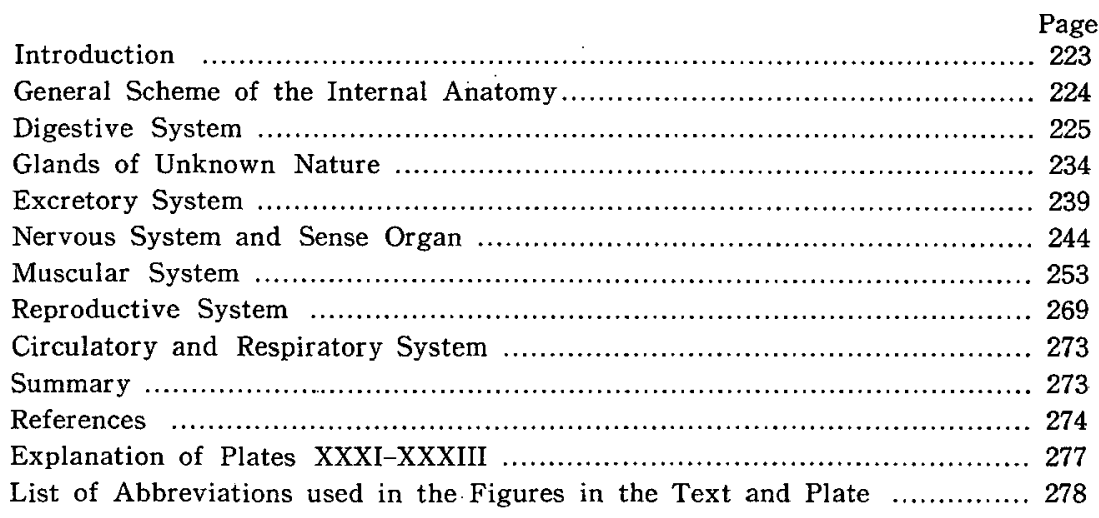

\section{Introduction}

This is a continuation of my "Studies on the Cirripedia Acrothoracica". As regards the ecology and external morphology of the female of Berndtia purpurea UTINOMI, the results of this investigation were already published in the first part of this series (UTINomi, 1957). In this second part the internal anatomy of the female will be treated.

As mentioned in the first of this series, the materials fixed and removed from the host corals, when necessary, by decalcifying with the Bouin's fluid, were carefully dissected under the binocular microscope and for detailed microscopical examination some of them were sectioned and stained by ordinary method.

1) Contributions from the Seto Marine Biological Laboratory, No. 353.

Publ. Seto Mar. Biol. Lab., VIII (2), $1960 . \quad$ (Article 18) 


\section{General Scheme of the Internal Anatomy}

As regards the internal organization of the Acrothoracica, very little is so far known with the exception of two genera Trypetesa and Cryptophialus, mainly studied by DARWIN (1854) and BERNDT (1903a, 1903b, 1907). These two forms are, however, rather extraordinarily specialized in structure among the group and show many peculiarities, not encountered in other forms. In the other forms almost as little is known of the internal structures, and since the internal organization has not been thought to be of much importance in classification, it has been described or illustrated too insufficiently to allow to make any comparative study. Therefore, the detailed accounts of the internal structures of this acrothoracican, as given in the following, may deserve to fill up some gaps in our present poor knowledge of the Acrothoracica.

Before entering into a detailed description of its parts, it seems necessary to give a brief account of the internal organization.

Fig. 1 shows a gross topography of the main internal organs and Fig. 17 shows the anterior portion of the body in more details. As shown in these figures, the internal organization is essentially the same as that of ordinary cirripeds (Thoracica). However, there may be found some important differences probably due to a remarkable prolongation of the prosomal region and to the absence of the peduncular region.

Of all the characteristics, the prolongation of both the alimentary canal and main nerve cord is the most remarkable. In comparison with those of ordinary cirripeds, the intestinal part of the alimentary canal is much lengthened, and the first thoracic (fused with the infra-oesophageal) and the terminal (formed of five thoracic ganglia fused together) ganglia are widely separated.

The oesophagus and oesophageal nerve-commissures are also much prolonged and run exteriorly (in ordinary cirripeds, interiorly however) to a small transverse muscle $\left(t_{1}\right)$ running across the head, and here abruptly bend downwards. This muscle apparently corresponds to the adductor scutorum muscle of ordinary cirripeds, but in reality it is not the same, as will be discussed later.

Most noteworthy is the fact that a pair of developed eyes which are unknown in other acrothoracicans exist in the connective tissue of the operculum close to the boundary between the head region and the operculum. The muscular system seems to be more complicated than in ordinary cirripeds and shows an ingenious construction so as to act for the remarkable contraction and extension of the body. Instead of the adductor scutorum muscle usually found in ordinary cirripeds, the so-called 'retractor orificii' (r.o) is strongly developed.

The sex is evidently dioecious, no male organ being found at all. The ovaries are lodged within the mantle on the rostral side where the external covering is thickened, extending upwards to form an attachment-disc. The other organs are 
not much different from those of ordinary cirripeds, though showing some peculiarities.

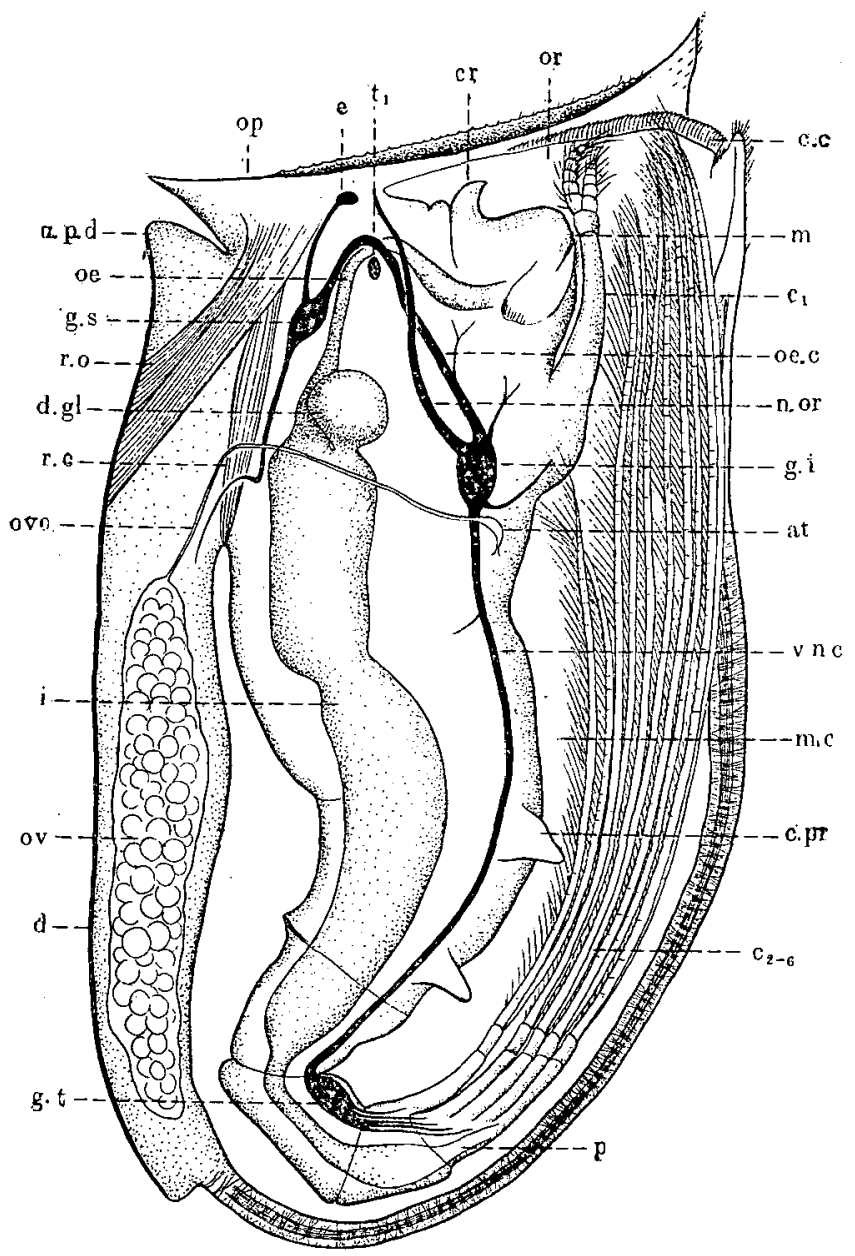

Fig. 1. General internal structure of the female of Bernitia purpurea UTINOMI, schematical. Lettering as on p. 278. [About $\times 30$ ]

\section{Digestive System}

TOPOGRAPHY. The alimentary tract, as would be expected, agrees in essentials with that of Lithoglyptes and Kochlorine among all acrothoracican cirripeds. It is composed of three regions, viz. the oesophagus $(o e)$, digestive intestine $(i)$ and proctodaeum $(p)$, and also of the paired digestive gland $(d . g l)$.

So far as I am aware, no investigation has been made to trace the embryonic 
development of these regions, yet it seems justifiable to consider that they correspond to the embryonic divisions of the ectodermal stomodaeum and proctodaeum, both lining with a cuticular investment, and the endodermal mesenteron, i.e. the mid-gut lacking any covering. In the present acrothoracican, however, it is still doubtful whether the terminal narrow portion of the intestine is wholly of the ectodermal origin.

The oesophagus runs backwards from the mouth parallel to and a little below the upper surface of the head facing the orifice, and then turns downwards

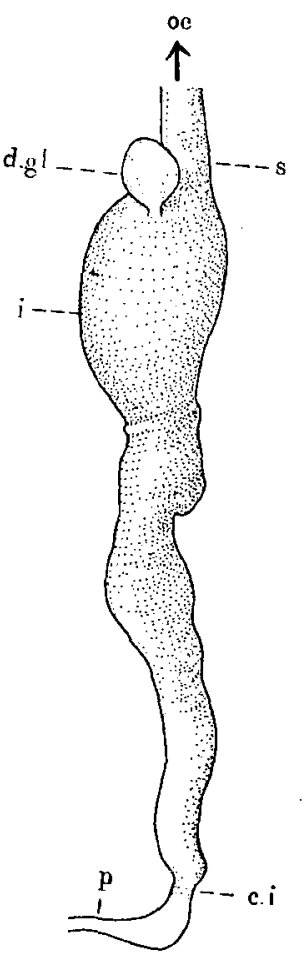

Fig. 2. Profile of alimentary canal, dissected out. Lettering as on p. 278. $[\times 40]$ perpendicularly; at its lower end the tract slightly enlarges, forming a funnel-like stomach $(s)$. Just below the point of curvature in the middle of the oesophagus, a powerful but small transverse muscle $\left(t_{1}\right)$ runs across; this muscle may correspond with BERNDT's 'adductor scutorum' in Cryptophialus minutus, but not truly so, as will be discussed later.

As mentioned above, the so-called 'stomach' is represented by a short but slightly widened last part of the oesophagus. In its dilated state it is difficult to determine its boundary towards the oesophagus by a mere superficial examination. Most of the earlier authors have mistakenly regarded a globular portion of the succeeding intestine or mid-gut lying in the prosoma as the stomach, but later on it was rightly demonstrated by BROCH (1919) in a detailed histological research of two pedunculate cirripeds, Anelasma and Scalpellum. More recently TöRNÄV ̈̈ (1948) called it the 'ventriculus' in his detailed study on the alimentary canal of Balanus improvisus.

The whole part of the oesophagus including the stomach occupies about one-third as long as the entire alimentary tract, and its anterior part lying horizontally in situ is somewhat longer than the vertically lying posterior part behind the point of curvature. As far as the relative length to the entire tract is concerned, the oesophagus in this acrothoracican resembles that of Scalpellum stroemi, but it is much more elongated than in most of ordinary cirripeds (cf. KRÜGER, 1940, pp. 94-95).

The intestine ( $i$, which is about two-thirds as long as the entire alimentary tract, runs posteriorly, lying close to the dorsal side of the thorax, towards the constricted part of the posterior portion, and then turns ventrally. The lumen of its anterior half, especially the foremost part, is always capacious and more than twice as broad as the oesophagus; sometimes it is here and there indistinctly 
constricted where the external cuticle of the thorax is transversely folded. Through a strong constriction lying towards the second thoracic segment (cf. Utinomi, 1957, fig. 6; Figs. 1 and 2), the intestine leads into the narrowed portion. It then becomes slightly wider and terminates in the anus situated between the bases of the last cirri on the dorsal side.

The anatomical and histological details of different main partitions (Fig. 2), comprising the oesophagus (oe), stomach $(s)$, intestine (i), digestive gland (d.gl) and proctodaeum $(p)$, are given as follows.

Oesophagus. The oesophagus (Figs. $3,6 \mathrm{~A}$ and $6 \mathrm{C}-6 \mathrm{E}$ ) is divided topographically into two parts, the anterior one lying horizontally and the posterior one lying vertically, both of which are bounded at the point of curvature in about the middle. The entire tract is covered by a homogeneous cuticle of even thickness; it is eosinophilous and in particular stains vividly with blue de Lyon. The cuticle (cut) consists of two layers, the outer striped thin layer (the so-called 'Stäbchenkutikula') and the inner thick smooth layer; the former is strongly chitinized, showing a somewhat yellowish hue and bears a thickness of about one-third of the latter. The cuticle is supported by a thick layer of the epithelium consisting of somewhat high and broad but indistinctly circumscribed cells $(e p . c)$; each cell has a large, round or ovoid, nucleus almost in the centre and richly pigmented around the nucleus. The radial dilatatory muscles, supporting the oesophagus from the external cuticle of the body, are very powerful and connected with the oesophageal cuticle by fine fibres inserted between the epithelial cells; the fibres of the dilatatory muscles lying downwards, i.e. dilatatores oesophagi inferior (d.oe.i), are very powerful and remarkably concentrated together on each side, each one forming a strong bundle covered with a continuously annulated sheath. Outside the epithelium, strong ring muscles $(r . m)$ circumscribe around the oesophagus, forming a distinct sheath; this is extraordinarily powerful near the mouth-opening, but decreases posteriorly and disappears a little before entering into the stomachal part. It is almost unable to diffrentiate the pure connective tissue cells or muscles between the oesophageal epithelium and the ring muscles, since the connective part (c.p) exhibits an almost 'sinew-like' appearance, filling with fibrous structures mingled with indistinctly circumscribed cells, although a few large nuclei occur here and there.

In spite of any careful examination on a number of sections (both longitudinal and transverse), any distinct bundle of longitudinal muscles has not been traced within the connective part between the epithelium and ring muscles. Regarding the problem whether the longitudinal muscles run along the oesophagus or not, earlier authors arrived at different conclusions. In Trypetesa lampas and Cryptophialus minutus, BERNDT pointed out the presence of longitudinal muscle, though weak and fibrous. The same opinion was followed by Genthe (1905) for Trypetesa lampas. 
In ordinary cirripeds, Nussbaum (1890) recognizes the presence of longitudinal muscles as interspersed in the connective tissue inside the ring muscles. According to Gruvel (1905), however, "Tout l'epace qui reste libre (between the epithelium and ring muscles) est rempli par le tissu conjonctif cellulaire dense".

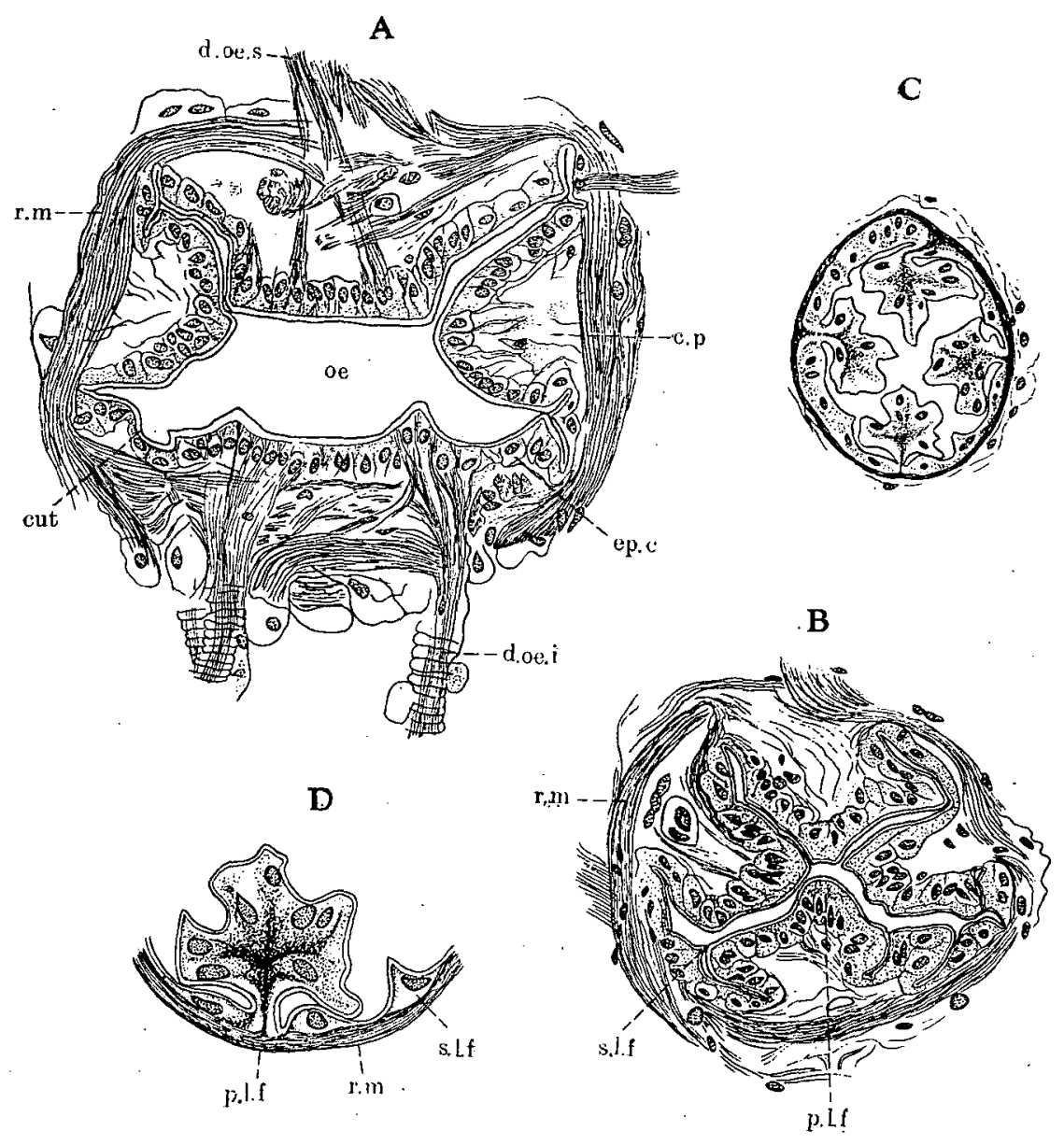

Fig. 3. A, transverse section of proximal portion of oesophagus. B, transverse section of oesophagus, a. little more backward than in the preceding figure. C, transverse section of posterior portion of oesophagus, D, a part of oesophageal epithelium shown in fig. C. Lettering as on p. 278.

$[\mathrm{A}-\mathrm{C}, \times 340 ; \mathrm{D}, \times 840]$

KnIPOWITCH (1892) also seems to have denied its presence in the example of the Ascothoracida, Dendrogaster astericola.

Concerning such different observations on the longitudinal muscles around the oesophagus, which are recently studied by Broch (1918) and Törnäv $\ddot{A}$ (1948) in more details for some ordinary cirripeds, KRÜGER (1940, p. 95) suggests that 
the longitudinal muscles or fibres are connective ('bindegewebig'), but TöRNÄV ̈̈ found in Balanus improvisus the longitudinal muscles as weak bundles alongside the ring muscles all throughout.

Transverse sections of the anterior portion (Fig. 3A) show a crossed wide lumen with four deep primary furrows stretched diagonally, two on each side. From the bottom of the primary furrow, two smaller secondary furrows branch off. Each of these furrows becomes narrower and deeper backwards, and the central lumen gradually tapers. The ring muscles surrounding it also become thinner and change their shape in cross section from having been somewhat four-cornered to form a round circle. Hence the posterior region of the oesophagus is about one-half as broad as the anterior region near the mouth.

In the posterior region, the oesophageal canal is surrounded by a thin layer of ring muscles $(r . m)$ and its inner wall is formed of four distinct folds, primary folds (p.l.f) are four in number and between them each a smaller secondary fold (s.l.f) is inserted. These folds, which are the direct continuation of the broad ridges inserted between the furrows mentioned above in the anterior portion, extend backwards till they become fused to one another and finally disappear at the transition to the stomachal part.

As is shown in cross section of this region (Fig. 3C-D), each of the primary folds consists of a narrow and short stalk and four-indented broad distal portion, apparently like a pinnati-parted leaf. The secondary fold between the primary ones is merely a slight elevation of the epithelium. The general appearance as stated above is almost akin to that of ordinary cirripeds such as Lithotrya nicobarica (SEWELl, 1926) and Balanus improvisus (TöRNÄvä, 1948), though they are less developed owing to the narrowness of the canal. In other acrothoracicans, so far as hitherto known, the corresponding folds seem to be rather irregular in arrangement.

The epithelial cells are almost cubical, wider and shorter in the posterior portion than in the anterior portion (Fig. 6C-D), and the nuclei are large and somewhat basally situated; the boundaries between the cells are generally indistinct. The cuticle covering the epithelial cells is continuous, and here and there touches directly with the ring muscles, where the epithelial cells are not inserted between.

Sтомасн. At the transition from the oesophagus to the intestine, a small region of the alimentary canal may be regarded as the stomach proper ('ventriculus' after TÖRNÄVÄ, 1948). This region (Fig. $4 \mathrm{G}, s$ ) is a little broader than the preceding part of the oesophagus and the boundary towards the oesophagus could not be distinctly defined by mere dissection because of the common ancestor, i.e. the stomodaeum.

The stomach proper is a rather wide, funnel-like lumen in the last part of the stomodaeum, where the longitudinal folds on the inner wall are largely reduced or even altogether absent. In sections, the inner wall is rather rugged 
owing to the epithelial cells of irregular height, but is always covered by a thin cuticle from the oesophagus. The epithelium is rather thinner than that of the oesophagus, and the cells are as a whole cubical, wider than high and contain a large nucleus centrally or basally (Fig. 6D). Here the ring muscles are quite

E
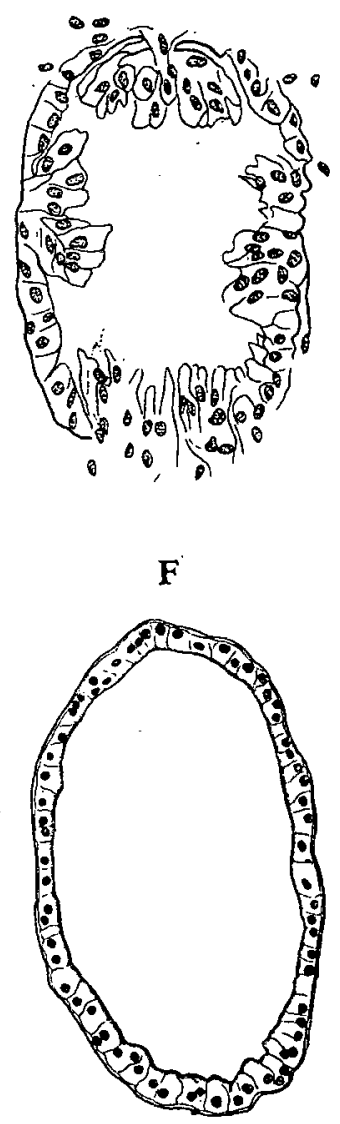

$\mathbf{G}$
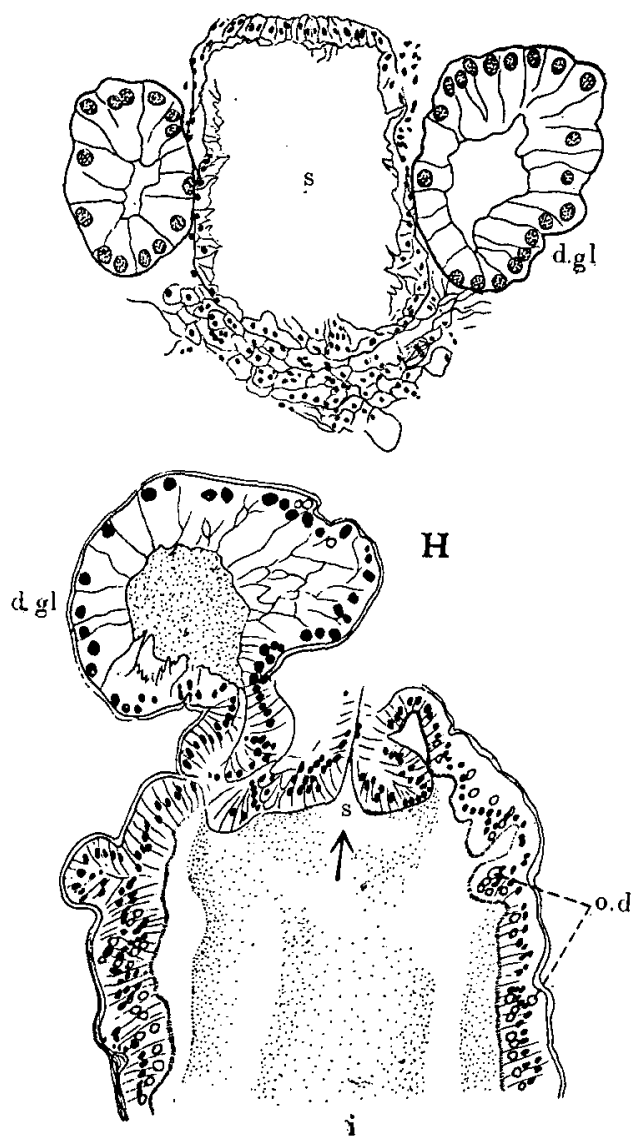

Fig. 4. E, transverse section of terminal portion of oesophagus, showing the transition to intestine. $F$, transverse section of intestine. $\mathrm{G}$, transverse section of stomach and digestive glands. $\mathrm{H}$, longitudinal section of digestive gland and proximal portion of intestine. Lettering as on p. 278. [F-H, $\times 140 ; \mathrm{E}, \times 340]$

lacking, but the cuticle covering the epithelium becomes more thinner and disappears at last at the transition towards the intestine (Fig. 5).

InTESTine. The endodermal part of the intestine consists of the mid-gut proper and the digestive (or gastric) glands attached to it. The intestine or mid-gut proper (Fig. $4 \mathrm{~F}, \mathrm{H}, i$ ) is only covered by the more or less thick epithelium 
which is supported by the continuous basal membrane (b.m) lacking any muscle. The epithelial cells are generally very high and narrow, though highly variable in different specimens. They exhibit a finely striped structure ('Stäbchensaum' after BERNDT's terminology) at the distal zone where is intensely stained a violet hue by Delafield's haematoxyline (Fig. 6F, st.s). This 'stripes' are always perpendicular to the surface in all sections and very distinct especially in higher cylindrical cells. Such a structure can be seen in other acrothoracicans as well as ordinary cirripeds.

The epithelial cells are uniformly cylindrical and finely granulated, and the nucleus which is usually situated in the central part of plasma, is round to oval in outline and as large as that of the esophageal epithelium, being about $4-6 \mu$ in

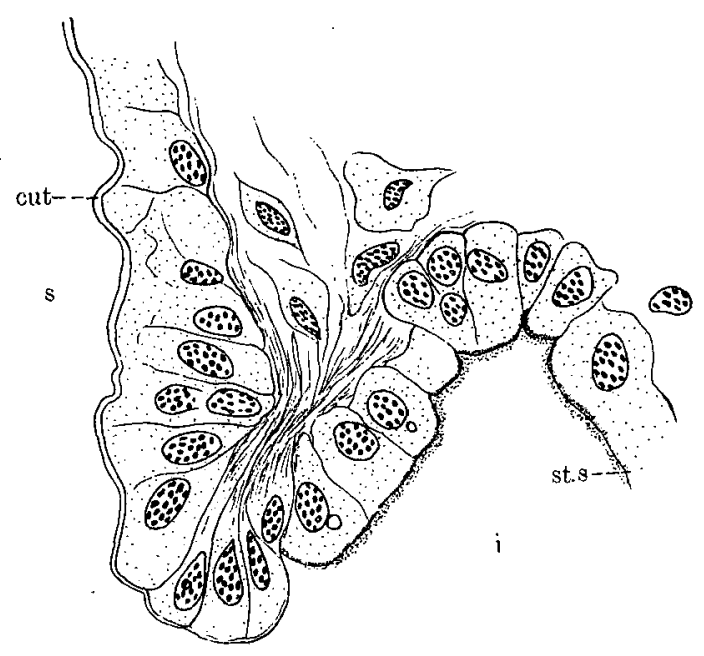

Fig. 5. Longitudinal section of alimentary canal at the transition from stomach to intestine. Lettering as on p. 278 . $(\times 840]$

diameter. The nucleolus could not be traced by the treatment with Delafield's haematoxyline, being only represented by a mass of numerous chromatic substances. Apparently yellowish-brown oil-drops, smaller than the nuclei, are sometimes scattered here and there (Figs. $4 \mathrm{H}$ and $5, o . d$ ). Practically they are much more abundant in the anterior part of the gut near the stomach, as seen in longitudinal section (Fig. $4 \mathrm{H}$ ).

These yellowish-brown drops are often found freely in the lumen of the gut, entangling with detritus of the food. Gruvel (1893) and Pyefinch (1936, 1937) also observed such drop- or granule-like secretion from the intestinal epithelium in ordinary cirripeds and ascothoracids respectively. I have not been able to find any special goblet-like secretory cells nor any of another form like NussBaum's gland cells (not figured by him) or BERNDT's 'Hepatopankreatische (Leder) Zelle'. 
The nature of these yellowish oil-drops or granules in the gut is obscure, but it is very likely that the secretion of the epithelial cells of the intestine is at least partly mucous.

Although superficially obscure, the boundary between the stomach and intestine is distinctly emphasized by a sharp constriction of the gut in longitudinal section (Figs. $4 \mathrm{H}$ and 5). At this constriction the cuticular covering continued from the stomach abruptly disappears, and both the dorsal and ventral ends of the epithelium profoundly protrude into the lumen of the gut. In the case of ordinary cirripeds, TöRNÄV̈̈ (1948) observed strong sphincter muscles at the transition from the stomach to the intestine in the sessile species Balanus improvisus, but $\mathrm{BROCH}_{\mathrm{RO}}(1919)$ did not find any sphincter muscles in the pedunculate species Anelasma squalicola and Scalpellum stroemi, as is also the case of this acrothoracican.

The intestine itself lacks the true cuticle and longitudinal muscles all throughout. In Cryptophialus minutus, BeRndT (1907), on the other hand, speaks of the presence of longitudinal muscles covering the alimentary canal. This is, however, very doubtful. It is likely that the so-called 'longitudinal muscles' around the intestine may be nothing but the real basal membrane. Likewise, the 'striped cuticle' or 'Stäbchensaum' in the intestinal epithelium, which was mentioned by Broch (1919, p. 20) is undoubtedly a mistake as pointed by KRÜGER (1940, pp. 94-98). It seems probable that this striped structure found in the distal part of the epithelial cells are, as mentioned above, the yellow granules secreting from the plasma (Fig. 6F, (st.s).

The lumen of the gut is usually filled with brownish slimy remains of food which have not been voided. Rather rarely it is wholly empty.

Digestive GLAND. A pair of large globular glands (Figs. 1, 2, 4G-H and 17, d.gl) open into the oral side of the stomach through two short and narrow ducts, one on each side of the stomach. This corresponds exactly with the digestive (gastric or pancreatic) gland found in ordinary cirripeds but unique for the group of Acrothoracica, having not been found in other known forms. Morphologically it resembles most closely that of Scalpellum stroemi figured by BROCH (1919, fig. 9). It measures in a large specimen about $0.2 \mathrm{~mm}$ in diameter.

The duct is short and narrow, but its wall is about as thick as the inner wall of the intestine. The glands and ducts are lined by a continuous basal membrane and lack any muscle as in the intestine.

Sections (Figs. 4G-H and 6B) show that the inner wall of the glands proper consists of very large and high cylindrical cells of the epithelium. The gland cells are densely filled with fine basophile grains, exhibiting a strongly alveolar appearance; they are here and there feebly vacuolized, almost lacking closely packed grains. The coarse alveolar network of the cytoplasm exhibits almost the same intense affinity to the dye as the cell membrane does, so that it conveys 
an impression of apparently consisting of a number of smaller cells. The boundaries between the cells are thus generally very difficult to trace. The cytoplasm is rather vacuolated in the distal part than in the basal part, but does not form any striped structure such as shown in the intestinal epithelium.

The nuclei (Fig. 6B-F, n) are invariably situated basally; they are oval to round and exceedingly large, apparently the largest of those seen in all somatic
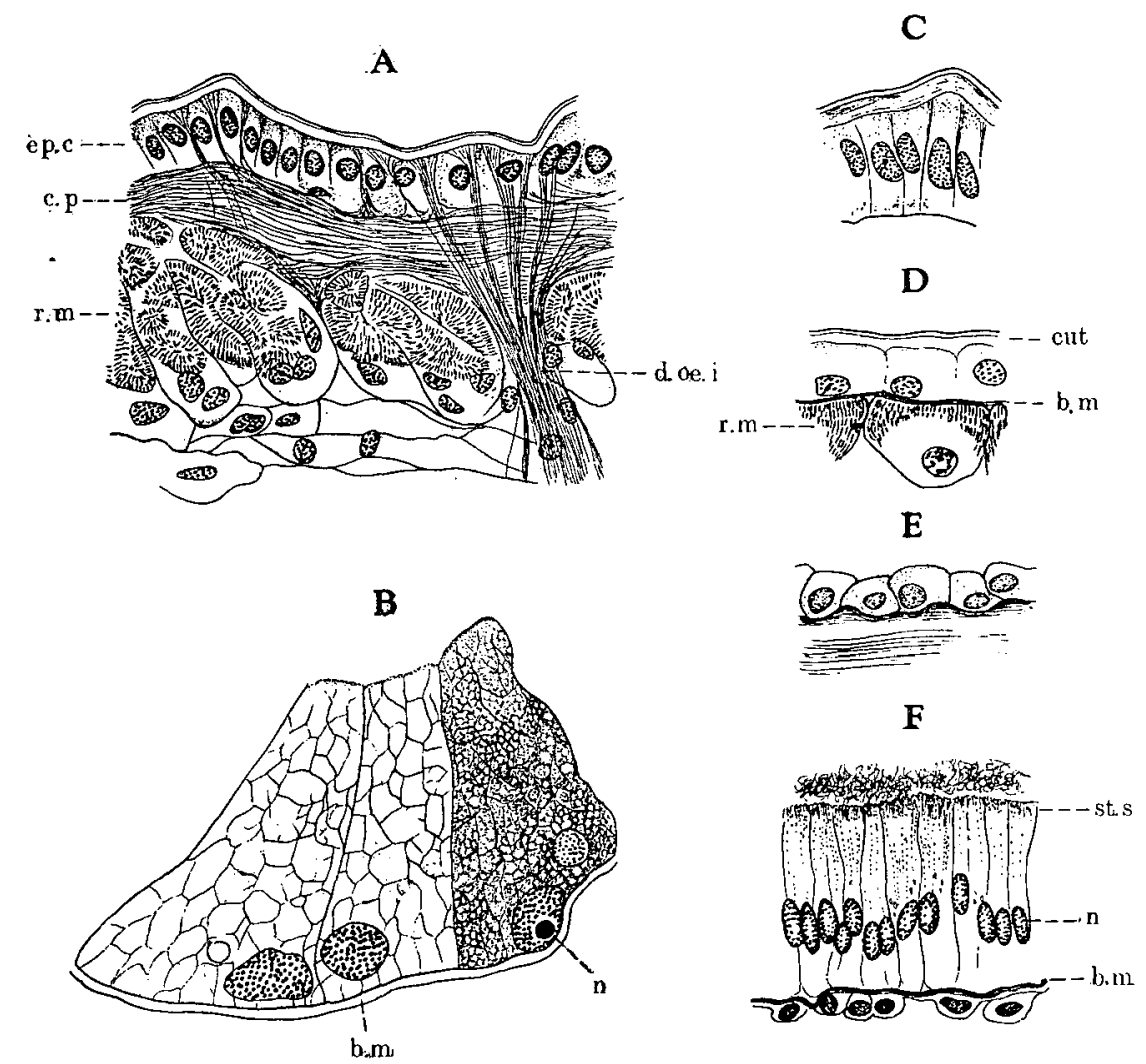

Fig. 6. A, Longitudinal section of oesophageal wall. B, epithelium of digestive gland. C, epithelium of intermediate portion of oesophagus. D, epithelium of posterior portion of oesophagus, $E$, epithelium of intestine in young specimen. $F$, epithelium of intestine in old specimen. Lettering as on p. 278.

$[\mathrm{E}, \times 340 ; \mathrm{A}, \mathrm{F}, \times 430 ; \mathrm{B}, \mathrm{C}, \mathrm{D}, \times 840]$

cells, as measured about $8-11 \mu$ in diameter, which size is about 1.5 to 2 times as large as the nuclei of the intestinal cells. They are richly furnished with chromatic substances, and now and then contain a large nucleolus in each one, which shows a less affinity to the haematoxyline than the former. The central lumen is roughly about one-half as large as the gland itself, and either empty or filled with mucus digested or secreted matter. 
As mentioned above, such digestive glands have not been found in other acrothoracicans. In the genus Trypetesa alone, however, the alimentary canal consists of a blind sac with many small evaginations and 'pit'-like depressions (Genthe, 1905; Tomlinson, 1953, 1955). Judging from the occurrence of peculiar very large, excretory cells which are called 'liver cells' (GENTHE) or 'gland cells' (TOMLINSON) besides the ordinary cylindrical cells in the intestinal epithelium, distributing evenly in the lining and also the lack of both cuticular covering and muscular sheath, the sac-like alimentary canal of Trypetesa appears to be essentially the intestine, not the 'stomach', and probably acts as a combined digestive apparatus of both the ordinary intestine and digestive gland described herein.

Proctodaeum. Just behind the terminal ganglion situated in the second thoracic segment, the alimentary tract is abruptly narrowed in accordance with the pronounced constriction of the thorax and then soon bends ventrally.

This narrowed last portion of the alimentary canal is the rectum or proctodaeum (Figs. 1 and 2,p). At the transition from the intestine, no structure answering to the sphincter as described by BERNDT (1907) in Cryptophialus minutus is found at all.

The proximal part of the proctodaeum is covered by a low epithelium consisting of cubical cells but devoid of cuticular covering; the cells contain a large, round to oval, nucleus in the center. Therefore, this part is evidently a direct continuation of the intestine but may be said a part of the rectum by its narrowness. A little way passing through the third thoracic segment, the canal becomes somewhat wider and then tapers gradually to the anus. Here the epithelium is extremely thin and lined only with a thin cuticular investment. The epithelial cells are nearly flat, hardly distinguishable and contain oval to oblong nuclei. The cuticle is thus continued from the external cuticle through the anus; it fades away obscurely before entering the constricted portion at the transition to the real intestinal part.

In transverse section (Fig. 33), this portion is shaped like I. Therefore, the terminal portion of the alimentary canal lying in the second to the last thoracic segments consists of the narrowed terminal portion of the real intestine and the proctodaeum. No muscle connecting with the proctodaeum is found. Generally speaking, the proctodaeum is built like the oesophagus but the ring muscles entirely disappear and the entire course is much shortened probably due to the extreme concentration of the main thoracic cirri at the end of the thorax.

\section{Glands of Unknown Nature}

Owing to the highly complicated structure of the body, the present acrothoracican like other cirripeds is rich in organs of indistinct nature. Of such organs, the digestive, 'salivary', maxillary and cement glands have been studied 
rather extensively by earlier authors. However, opinions concerning their structure and function are often diversified, possibly because of their anatomical investigations being confined to a few species. Hence, there still remained many problematical points in their anatomy and histology requiring further detailed comparative study. Of these glands the digestive glands found in this acrothoracican has already been described. The following is the observations on the other glands or organs of indistinct nature found in this acrothoracican.

'Poison GLAND' or 'Salivary GLAND'. On the ventral side of the infraoesophageal ganglion, though lying somewhat more upwards, there is a peculiar mass of glandular cells.

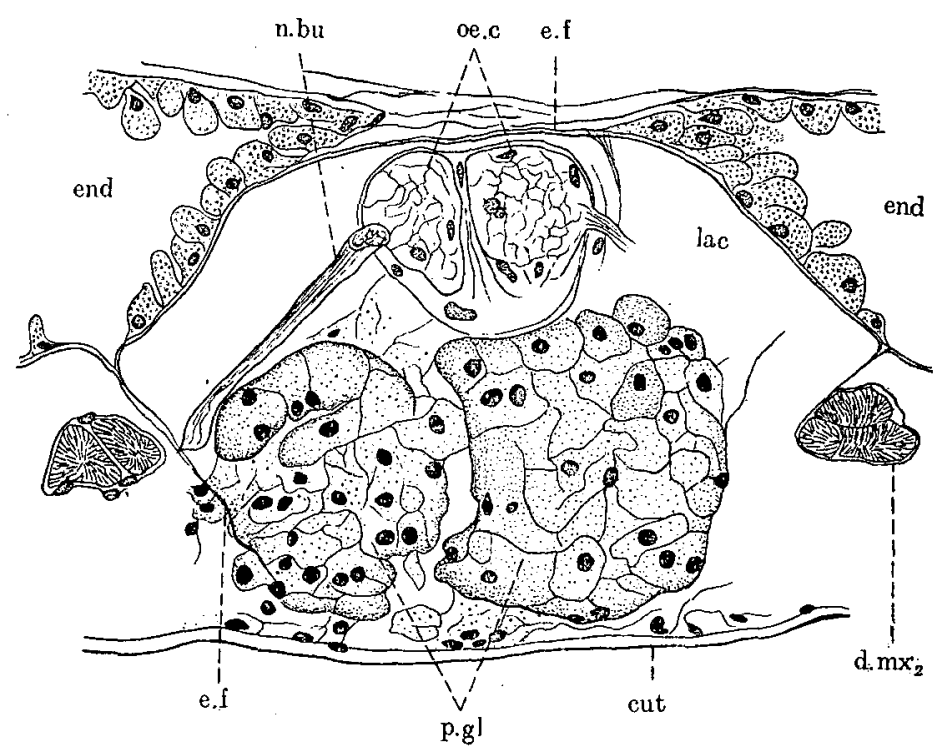

Fig. 7. Sagittal section of 'poison gland' and its surroundings. Lettering as on p. 278 . $(\times 340)$

In longitudinal section through the medial axis of the body, the gland in question (Fig. 18) is shown by a fan-like shaped assemblage of gland cells, and its main part is situated below the invagination of the external cuticle at the base of the mouth; then it extends to the base of the upper lobe of the second maxilla, tapering gradually. But there is no indication of a common duct nor communication to the exterior at the end of these cells.

The outline of this gland is apparently variable and bears no common investment around the cells. It can only be defined from elsewhere, as they are gathered together in two bulb-like groups. The main part (Fig. 7, p.gl) is imbedded within the large lacunae between the external cuticle and infra-oesophageal ganglion and supported from both sides by the elastic fibres (e.f) which 
are continued from the basal membrane of the maxillary glands ( $m x . g l$ ) situated on both sides. Serial transverse sections clearly indicate that the glands are paired, one on each side, though their main parts are closely connected medially.

The entire organ is composed of many, large and prolonged bottle-shaped gland cells, not less than 50 in number on each side. The nuclei are round in outline, as large as $7-8 \mu$ in diameter and situated in the centre of the lower swollen part; a large nucleolus is distinct in each of them. The protoplasm is apparently homogeneous and evenly granulated in the lower swollen part; the upper narrowed part is somewhat coarsely granulated but never vacuolated, as it is uniformly stained with Delafield's haematoxyline. Any direct communication with the alimentary canal or with the exterior could not be traced. Judging from the direction of the gland cells, however, it seems probable that the secretion, if present, is conveyed to the external epithelium of the second maxillae through the upward prolongation of the cell which serves as the duct.

This gland reminds one of the so-called 'salivary gland' which corresponds with 'Undefinirbare Organ 2' of Nussbaum (1890), 'glande salivaire' of GRUvel (1904, 1905) and 'glandulae salivales' of Törn Äv Ä (1948) found in ordinary cirripeds. It seems also to be identical with 'Organe énigmatique' of BERNDT (1907) in Cryptophialus minutus which lacks the external opening and vestige of secretions. In another acrothoracican Trypetesa lampas, BERNDT (1903a) discovered a similar assemblage of gland cells with its own external opening at the same position, and he regarded it as the salivary gland.

Judging from the accordance of their position, it seems probable that the gland in question found in ordinary cirripeds and acrothoracicans are of the same origin, although may have been differentiated functionally, with or without the direct communications with the exterior.*) However, its homology with the real salivary gland in other animals is open to question.

If we bear in mind that such small epizooic animals at all events mainly prey upon smaller zooplankters and that there is no direct communication between the alimentary canal and the gland in question, BROCH's supposition that it is the poison gland seems to be more reasonable than the opinion that it is the salivary gland. However, the final solution must await physiological investigations.

EosinophILous BODY. Besides the gland mentioned above, two enigmatic bodies of remarkable feature are found in the cephalic region (Fig. 10,e.b). They consist of two similar bodies, occurring in close contact with the second trans-

*) In this connection, we remember the peculiar spiniferous protuberances or bosses usually found at the base of the first cirri in the pedunculate cirriped genus Oxynaspis. Concerning this peculiar protuberances found in $O$. pulchra, Nilsson-Cantell (1934, p. 50) states that "The small spines (of the protuberances) seem to have a fine central channel with the opening at the top of the small cone. The function of this peculiar formation is difficult to decide". It is likely that these openings on the top of the peculiar protuberances (cf. his fig. $1 j$ ) correspond with the external openings of the above-mentioned gland in question. 
verse muscle $(t)$ running across the thorax a little below the proximal portion of the oesophagus. Its situation to the said muscle is either forwards or backwards.

Sections (Fig. 9) show that each one is generally oval, spherical or sausageshaped, measuring about $0.05-0.09 \mathrm{~mm}$ in longest diameter. The protoplasm appears to form a reticular or granular structure which exhibits uniformly a pronounced affinity to eosin and contains in the central part an assemblage of nuclei, ranging from 10 to 20 in number. The nuclei are relatively large, about

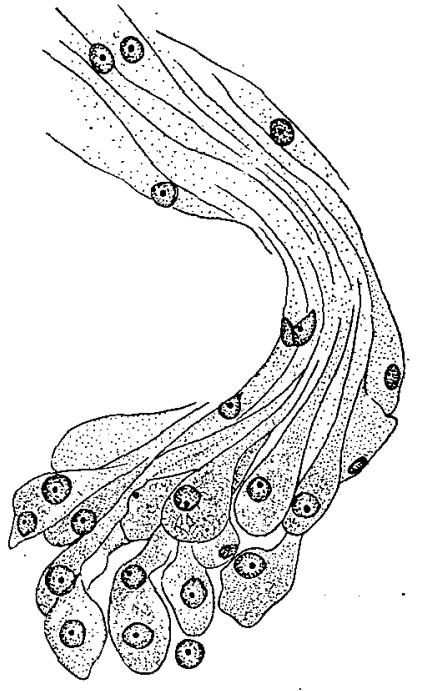

Fig. 8. Longitudinal section of 'poison gland': $\{\times 420]$
A

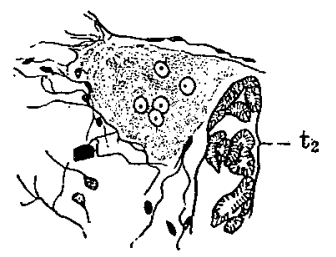

B

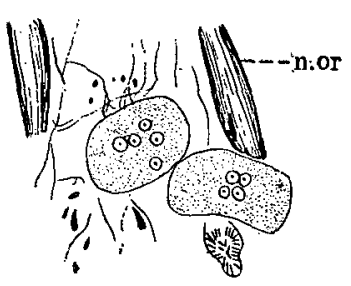

C

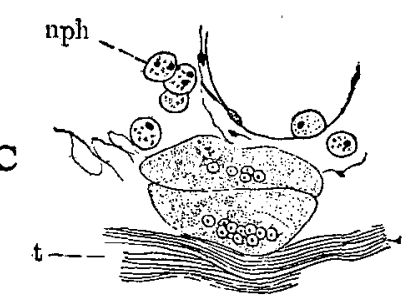

Fig. 9. Eosinophilous bodies of unknown nature. A, longitudinal section. $B$, frontal section. $C$, transverse section. Lettering as on p. 278 . (All $\times 210$ )

5.5-6.5 $\mu$ in diameter and each provided with a distinct nucleolus around a few other chromatic grains. The body in question shows no organic connection with the surrounding tissue, since it is lined wholly with a delicate basal membrane which here and there contains spindle-like nuclei as in the other organs. Thus it is evidently a cell-complex perfectly fused together as an independent body. However, the nature of this body remains quite unknown to me and likewise it is unable to say whether it is of a glandular function or not. 
Nothing recalling such structure has been described by earlier authors in any other acrothoracicans and ordinary cirripeds. Curiously enough, however, it resembles somewhat the two bodies of unknown nature which was ever found by HoEk (1884) in the male of Scalpellum regium; they are, according to him, of an oval bag slightly pointed at one or both extremities, lined by an extremely delicate membrane and filled with a granular substance of a brownish-yellow colour, having numerous nuclei scattered throughout its interior (cf. HoEK, 1884, p. 14 ; Pl, I, fig. 2, gl). He supposed them to be the remains of the cirral appendages of the cypris-stage. But this supposition seems incredible.

Though there is no evidence for supporting that this eosinophilous bodies in this acrothoracican and those found in the male of Scalpellum regium are similar in nature, I have often met with fine yellowish granules scattered in the interior, something like the same-colored excretes contained in the nephrocytes which will be referred to later. The yellow granules found in the interior are, however, broken into so minute debris that they can be scarcely defined. This fact may deserve a special notice in connection with its situation in the connective tissue of the cephalic region, where the nephrocytes are scattered throughout in great numbers. No other structure has been revealed. Therefore, it seems to me that they probably represent an organ related to the excretion or intracellular digestion or ally.

Cement giand. Finally, some remarks on the so-called 'cement gland' in the Acrothoracica may be added here.

In Trypetesa lampas, DARwIN (1854) pointed out the complete lack of cement glands which occur usually in ordinary cirripeds. BERNDT (1903a), nevertheless, asserts its presence at the same position as in ordinary cirripeds; it is, according to him, situated under the disc, though unpaired and somewhat rudimentary, lacking the duct. In Cryptophialus minutus, however, he failed to find it (BERNDT, 1907, p. 193).

In my opinion, the 'cement' called by BERNDT is nothing but the cuticular coverings piled up along the disc and the 'Cementzellen' are probably the sexual cells of the ovaries or oviducts.

In the present acrothoracican I could not trace any structure referable to the cement glands of ordinary cirripeds, especially in the pedunculate group. Therefore, I strongly suspect that if it occurs at all, it is still in a rudimentary state and the cells have not been differentiated enough to stain differently from other cells. Indeed, KüHNERT (1934) has demonstrated from a developmental study of Trypetesa lampas, that 'Klebdrüse' (adhesive gland or larval cement gland ?) which opens at the end of the antennules falls to ruin after settlement. Anyhow, it seems probable that the so-called cement gland is completely lacking at least in the adult, being only functional in its larval life. 


\section{Excretory System}

The excretory organs do not differ in all essentials from those of other acrothoracicans and ordinary cirripeds. However, the most noteworthy is the occurrence of the so-called 'nephrocytes' or 'athrocytes' which have been observed by BRUNTz (1904) in a sessile barnacle, Balanus tintinnabulum.

MAXILLARY GLAND. The excretory organs of the Cirripedia have long been a subject of much discussion, and it is only recently that their structure has been ellucidated.

DARWIN (1854) at first considered a pair of pores on the outer sides of the second maxillae to be the 'olfactory organs'. About thirty years later, Hoek (1884) referred them to the 'segmental organs'. Since then the same organs have been studied by many authors such as NusSBaum (1890), KoEHLER (1892), Bruntz (1902, 1904), Berndt (1903a, 1907), Hoffendahl (1904), Gruvel (1905), Defner (1910) and Nilsson-Cantell (1921). The last-named two authors have given a precise account on this subject, summarizing all previous works.

Of the acrothoracicans, only three forms (Trypetesa lampas, Cryptophialus minutus and Lithoglyptes indicus) have been investigated as to these organs.

As shown in Fig. 23, the maxillary glands ( $m x . g)$ are situated on both sides just below the mouth, with portions extending into the second maxillae and passing posteriorly. On each side it consists of three parts: endosac (Nussbaum's 'Kiemenniere', BRUntz's 'saccule', Berndt's 'secernierender Teil', Defner's and Nilsson-Canteli's 'Endnsäckchen'), urinary bladder (KoehleR's and Gruvel's 'cavité générale', BRuntz's 'labyrinthe', BERndt's 'ausführender Teil', DEFner's and Nilsson-Cantell's 'Harnkanal') and urinary duct (HoEk's 'segmental duct', Bruntz's 'canal excreteur', Defner's and Nilsson-Cantell's 'Harnleiter').

A little below the second maxilla on each side, there may be seen a slight swelling and within it a large and dark-colored globular mass. This globular mass represents the endosac (Figs. 11 and 12 , end). It lies between the bases of the mouth-cirrus on each side and the infra-oesophageal ganglion in the medial part, as clearly shown in a frontal section (Fig. 10). Serial transverse sections (Plates XXXI-XXXII, Figs. 3-5) show that the endosacs of both sides are remarkably large and roughly oval in outline, somewhat extending inwards, where they are connected together by the elastic fibres (Figs. 7 and $12 \mathrm{~B}, e . f$ ) on the dorsal side of the infra-oesophageal ganglion. Here these elastic fibres traverse between the orificial nerves and oesophageal commissures on both sides; similar fibres connect the ventral wall of the endosac with the external body wall on both sides of the infra-oesophageal ganglion. The endosac proper is slightly apart from the body wall of lateral sides and supported by several fine connective tissue fibres to the latter, a large lacunar interspace being inserted between them. In frontal sections (Figs. 10 and $12 \mathrm{~B}$ ), it is shown as a three-cornered sac. 
The endosac is surrounded continuously by a thin basal membrane (b.m), and its inner wall consists of large peculiar excretory cells which contain the brownish yellow grains of excretes richly within the plasma, and thus contrasts markedly with that of the urinary bladder. The excretory cells (Fig. $11 \mathrm{~A}$, ex.c) are very large and variable in form, ranging from cubical, globular to flask-like; they are generally ball-shaped in the distal part and more or less constricted towards the base. The nucleus is round or oval and usually situated basally; it contains

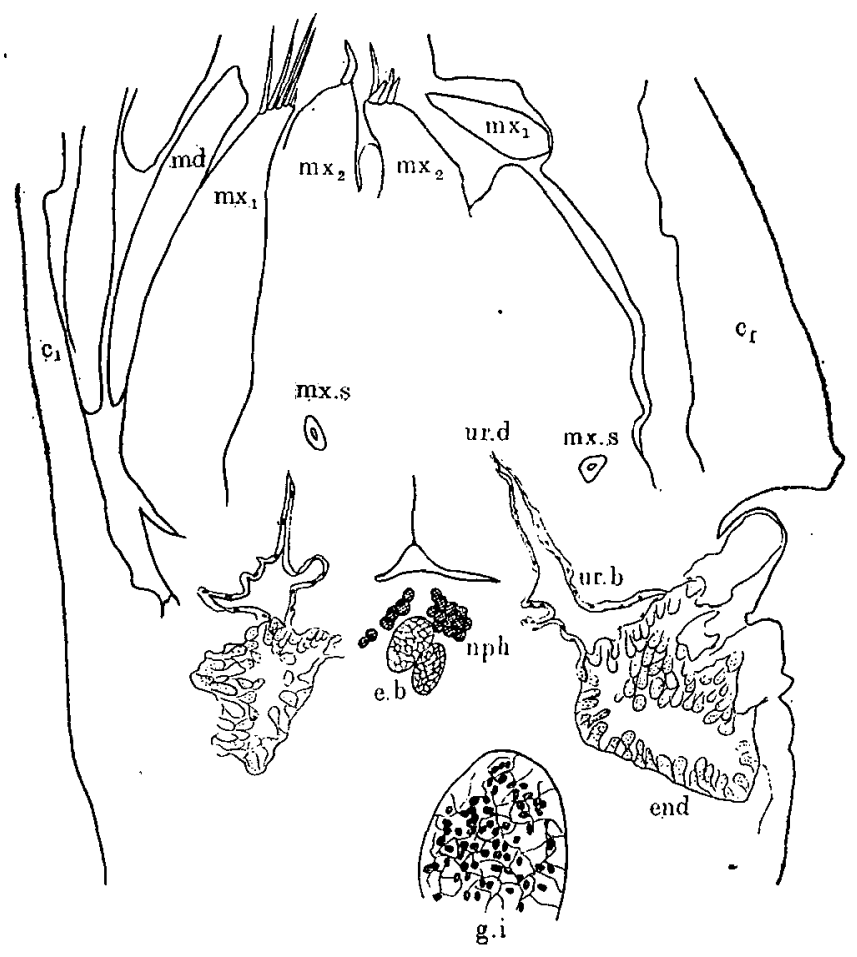

Fig. 10. Frontal section of head portion of body across oral cone, showing maxillary glands and eosinophilous bodies of unknown nature. Lettering as on p. 278 .

$(\times 140]$

chromatic substances which are stained strongly with Delafield's haematoxyline, but the nucleolus could not be found.

Concerning the function of the maxillary gland, it is generally admitted that the endosac is a main organ of excretion, even though not at all. Johnstone and Frost (1927) alone, however, reject it. It seems probable that the excreted matter is detached off by constriction from the cell proper and converted into DEFNER's 'Wolken' within the endosac, then it will be ejected to the exterior through the urinary bladder and duct (Figs. 11 and 12, ur.b and ur.d). 
Apparently most of the earlier authors took no care of the fate of the nuclei of the excretory cells during the course of function. For example, DEFner (1910, p. 198) mentions only that ".......sich Zellen samt Kernen als Exkretkugeln vom Epithel loslösen, in das Lumen gelangen und dort platzen". In most of the gland cells, however, such case seems to be rather rare, since the nuclei generally remain undetached in the cells, even when the excrete globules (Fig. 12 A, ex.g) formed in the distal part were cast off. In the present case, the excretory cells, when fully developed, become taller and pyriform or lacrymaeform in shape as the result of a strong constriction at their bases; then the whole part of the cell,

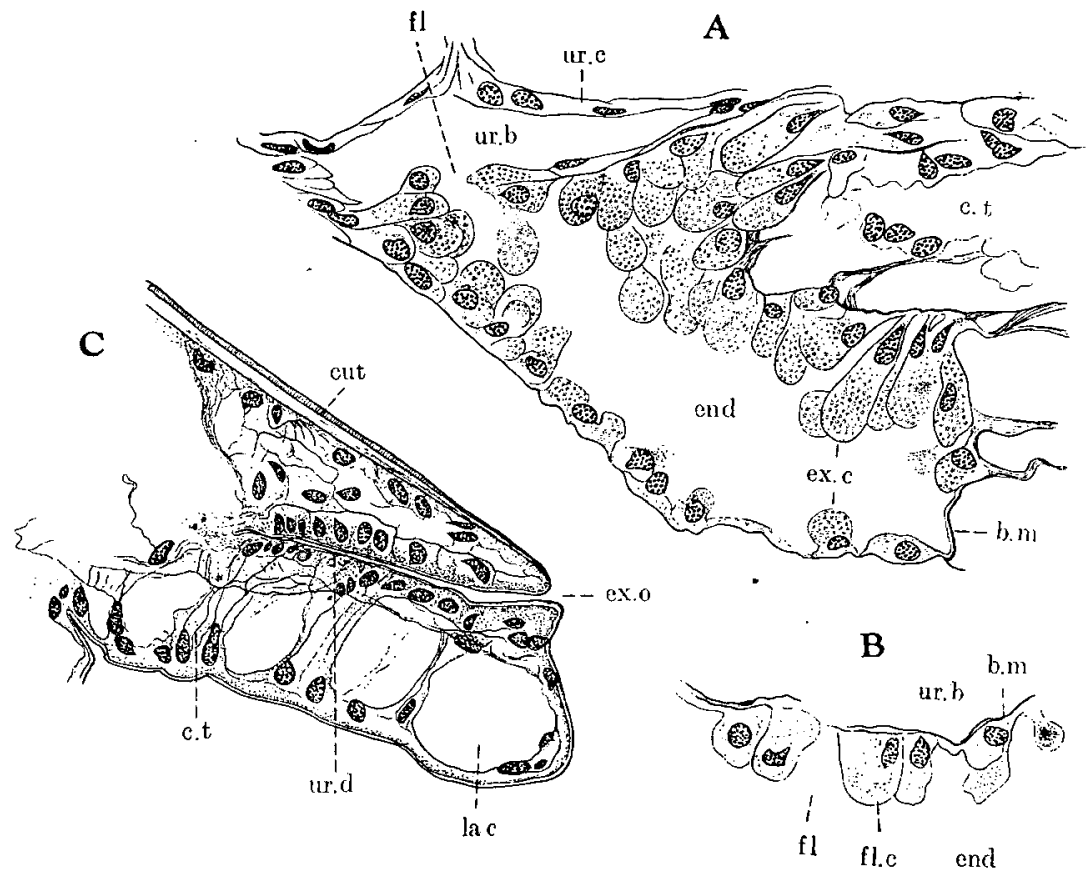

Fig. 11. A, longitudinal section of endosac and urinary bladder. B, communication between ecdosac and urinary bladder. C, longitudinal section of urinary duct. Lettering as on p. 278. (All $\times 450]$

packed richly with the excretes, shows an appearance to be almost detached off from the base, together with the own nucleus lying close to the base. Still the nucleus is not actually detached off, but it remains at the base as it is stretched. The excretory globules thus formed in the distal part and those free in the lumen will be torn and the excretes within them finally burst out. But this is not always the case. I have frequently observed that the distal part of the cells becomes greatly expanded and the excretes are discharged by breaking the tip without formation of constriction at the base. 
The urinary bladder (Figs. 11 and 12,ur.b) is situated on the upper and inner side of the endosac and connected by a narrow funnel $(f l)$. They on both sides are widely separated, as shown in Fig. 10. Such a mutual communication by a canal between them on both sides, as described by BERNDT (1907) for Cryptophialus minutus, does not occur.

Unlike ordinary cirripeds, the urinary bladder is much smaller than the endosac and roughly triangular in outline, as shown in either longitudinal or transverse section. The inner wall is covered by a thin epithelium everywhere. The epithelial cells $(u r . c)$ are thus flattened and contain spindle-like nuclei lengthened parallel to the basal membrane. The lumen was empty at all, lacking any excrete-globules.

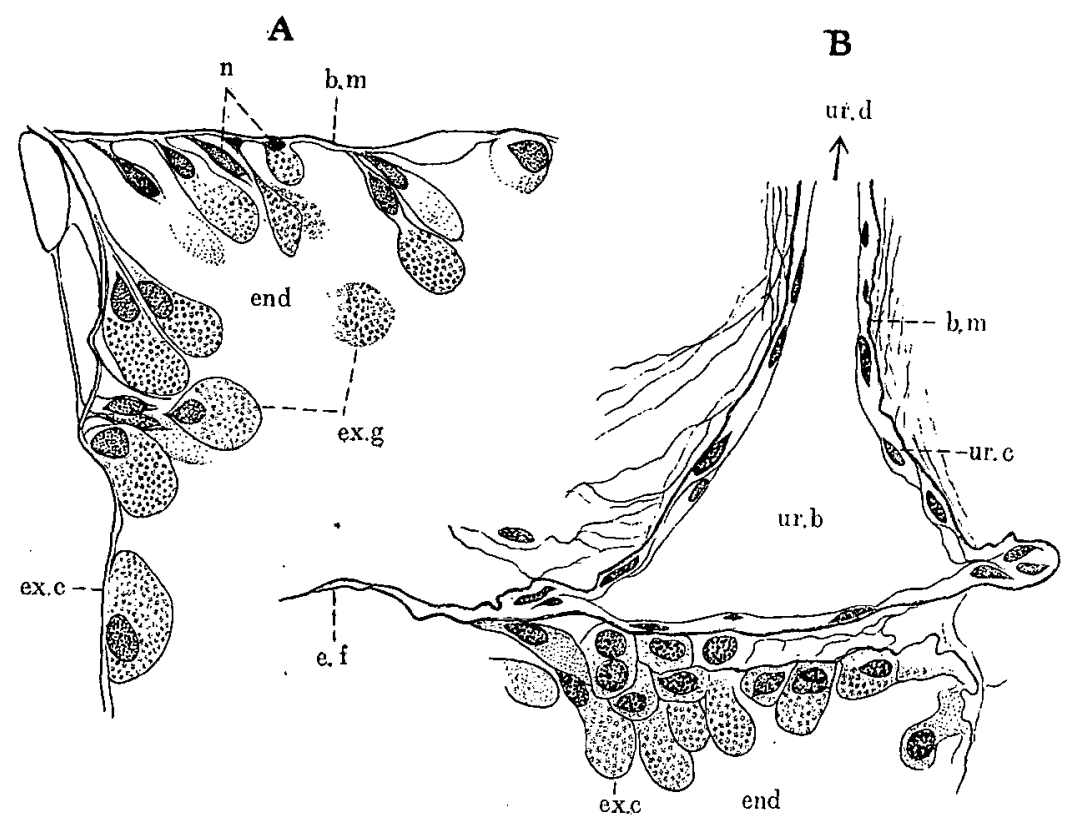

Fig. 12. A, epithelial cells of endosac. $B$, frontal section of urinary bladder. Lettering as on p. 278. ( $\mathrm{A}, \times 840 ; \mathrm{B}, \times 700)$

The urinary duct (Figs. 10 and $11 \mathrm{C}, u r . d$ ) is very small and narrowed to the opening, so that only traceable all throughout in the most favorable section. It opens near the ventrolateral corner of the lower lobe of the second maxilla on each side and covered by a very thin cuticle which is continued from the external thoracic cuticle. The cuticle consists of two layers, the outer striped and the inner smooth. This speaks for that the duct as well as the bladder is of an ectodermal origin.

CEPHalic NEPHROCYTES. In addition to the maxillary gland, it is interesting to report the occurrence of the so-called 'nephrocytes' which may be another sort of excretory organs. 
As clearly be shown in any sections, there are numerous mass of exceedingly large and round cells scattered all throughout the whole part of the connective tissue of the cephalic region, especially in its median part lying on the ventral or lower side of the oesophagus. Generally they occur freely in the lacunae and often crowded together.

These cells (Fig. 13, nph) are mostly round in outline and about $20 \mu$ in diameter, ranging from $12 \mu$ to $25 \mu$; each one is usually provided with two (rather rarely one or three) large nuclei of about $5 \mu$ in diameter. However, there is no indication of cell division between the nuclei. When treated with the double staining method of Delafield's haematoxyline-eosin, the nuclei display an intense affinity to the haematoxyline, while the cell membrane to eosin. In addition, they contain invariably many brownish yellow grains, resembling those within the

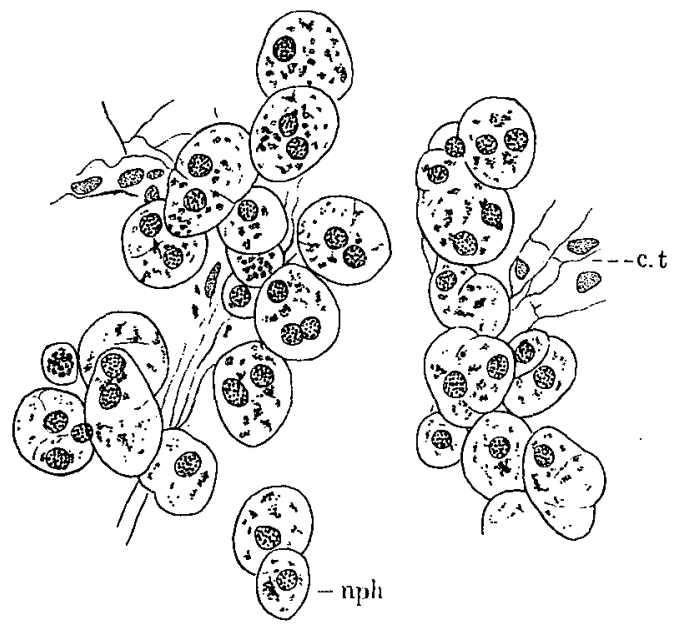

Fig. 13. Mass of cephalic nephrocytes. Lettering as on p. 278 . $[\times 450]$

epithelial cells of the endosac mentioned above. These grains are thus possibly of the same kind and may be excretory products stored within, instead of being expelled from the body. The remaining part of the cells is stained intensely with eosin, leaving the surroundings of the grains only where are less stained or unstained, so that minor structure of the plasm cannot be clearly defined. But presumably the plasm is more vacuolated than fibroid. No other free mesodermal cells containing such yellow grains could be found in the body cavity, except for the above-mentioned eosinophilous enigmatic bodies.

As can be deduced from the above description and figures, these peculiar cells recall strongly the 'néphrocytes à carminate' called by CuÉNOT and BRUnTz, which name was afterwards changed by Burian (1924) as 'athrocyten'. Especially, BRUnTz $(1902,1904)$ made an extensive study on the mechanism of 
excretion in various groups of crustaceans by means of the injection method and emphasized that the secretion in the Cirripedia is performed by three organs, such as 'reins maxillaires' (maxillary glands), 'néphrocytes à carminate' and 'glandes hepatiques' (digestive glands). Concerning the second-named organ, he discovered it in Balanus tintinnabulum and described it in detail; in this barnacle, according to him, two cell-masses shaped like a concave-convex lens are found in the connective tissue on both sides of the cephalic region, and the cell-masses are round, about $30 \mu$ in the longest diameter and contain two nuclei of a diameter of $3 \mu$, together with yellow grains and carmine precipitations.

In the present acrothoracican, however, the cells are more scattered and the nuclei are of lesser size. Apparently the size of these cells as well as the nuclei may $b$ dependent on the body size of the animal.

As to the function of the nephrocytes, BRUNTz (1904, p. 251) states that “......ces nouveaux organes (néphrocytes) sont placés justement sur le passage du sang, allantet revenant du manteau, condition favorable pour que ces cellules, toujours lavées par le courant sanguin, puissent en retirer les produits destinés à être éliminés".

Although his account on its function has been mainly based on the physiological experiment, it seems probable that certain waste products of metabolism ejected by means of blood circulating to and fro through the blood lacunae are partly discharged to the exterior by the maxillary glands and probably the digestive glands too, and partly accumulated and stored up in the cells of nephrocytes lying freely in the lacunae and then absorbed by their phagocytic activity at last. Hence the nephrocytes may serve only as a supplementary organ for excretion, directly connected with the circulation of blood.

\section{Nervous System and Sense Organ}

Topography. Owing to the small size of the animal (less than $5 \mathrm{~mm}$ in total length), it is very difficult to dissect the body and to trace the whole nervous system. It is only successful by reconstruction from serial sections of the total body, besides the total dissection.

The nervous system of this acrothoracican shows many important peculiarities not seen in other acrothoracicans but partly may be seen in ordinary cirripeds. Generally speaking, it resembles that of the pedunculate group on one side and that of the sessile group on the other, apparently representing a somewhat intermediate feature between the two groups of ordinary cirripeds.

The nervous system consists of two main nerve masses; the one is the cerebral or supra-oesophageal ganglion and its offshoots lying on the dorsal side of the body, and the other the two fused ventral ganglia and their offshoots lying on the ventral side. Both ganglia are connected by a pair of commissures passing around the oesophagus (Fig. 14). 
The cerebral or supra-oesophageal ganglion ( $g . s$ ) is situated behind the posterior portion of the oesophagus. It is smaller than the two ganglia on the ventral side, and formed of two lateral lobes which are fused together at their lower halves, having a median depression in the upper halves.

Each lobe becomes narrower upwards to form an oesophageal commissure entering around the oesophagus. From the upper end of each lobe, dorsal to the oesophageal commissure, a small nerve arises and runs upwards to the
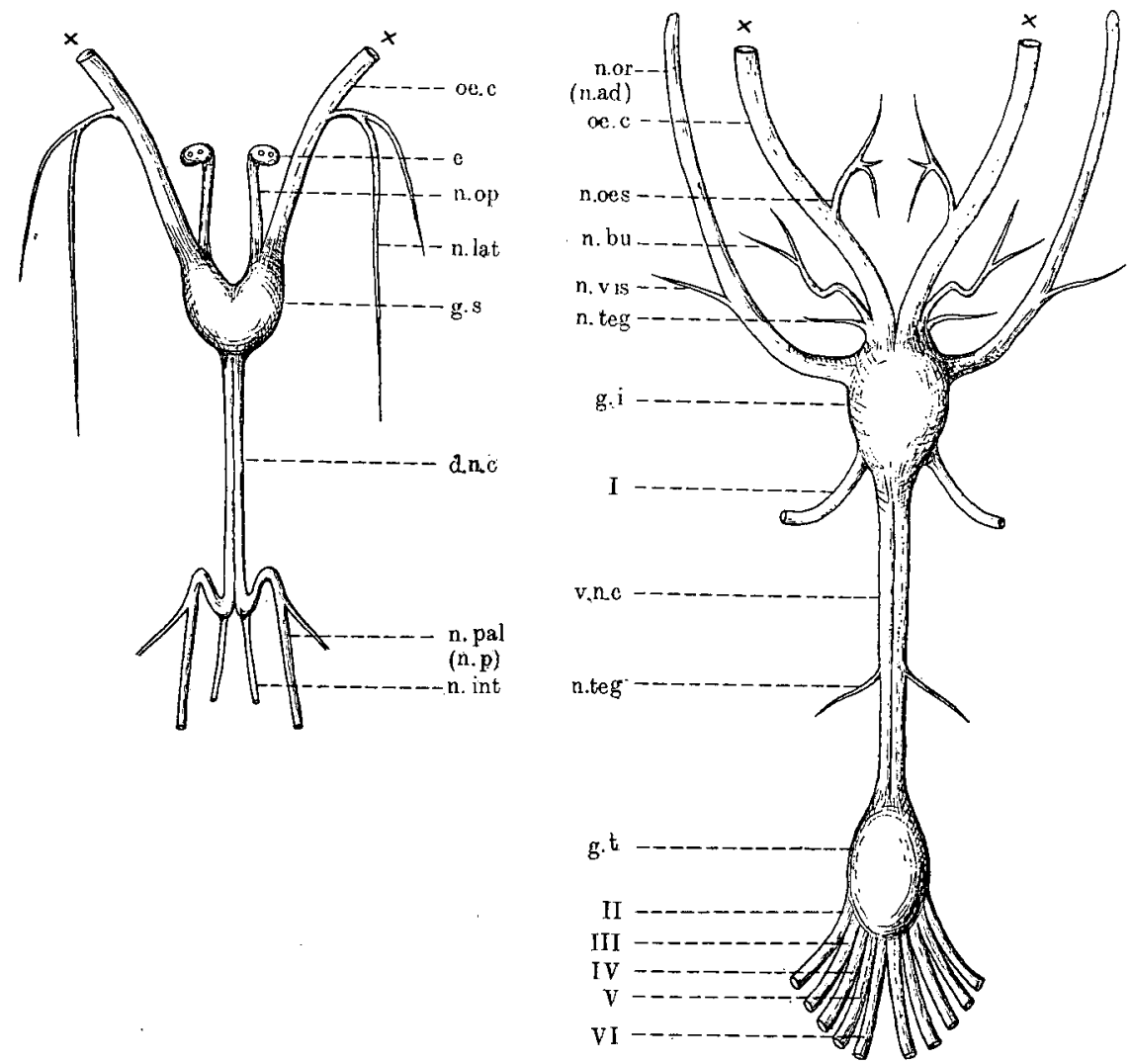

Fig. 14. Schematic figure of the nervous system. The cords lying dorsally are shown on the left side and those lying ventrally are on the right. Roman numerals show nerves running to the respective cirri. Other lettering as on p. 278 .

operculum, ending to a rounded lobe; this nerve and terminal lobe certainly correspond with the optic nerve $(n . o p)$ and optic ganglion or eye $(e)$ respectively, which occur in the majority of ordinary cirripeds.

From the lower fused end of the cerebral ganglion, a broad nerve cord extends straightly downwards for some distance along the dorsal side of the oesophagus; on closer examination, however, it may be defined that the cord is 
in reality formed of two cords closely united. This dorsal nerve cord (d.n.c) as I here named is composed of two nerves arising from the two lobes of the cerebral ganglion and coated with a common sheath (Fig. $15 \mathrm{C}$, sh). Both nerves become to run separately from a little below the commencement of the intestine; then one smaller branch (n.int) runs straightly downwards along the intestine, while

C

D

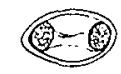

$\mathbf{E}$

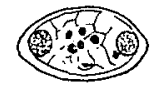

$\mathbf{F}$
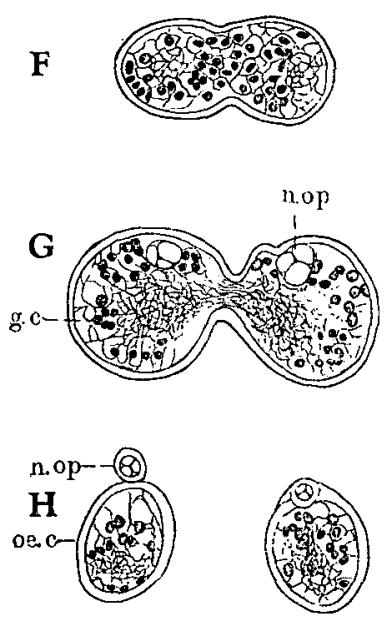

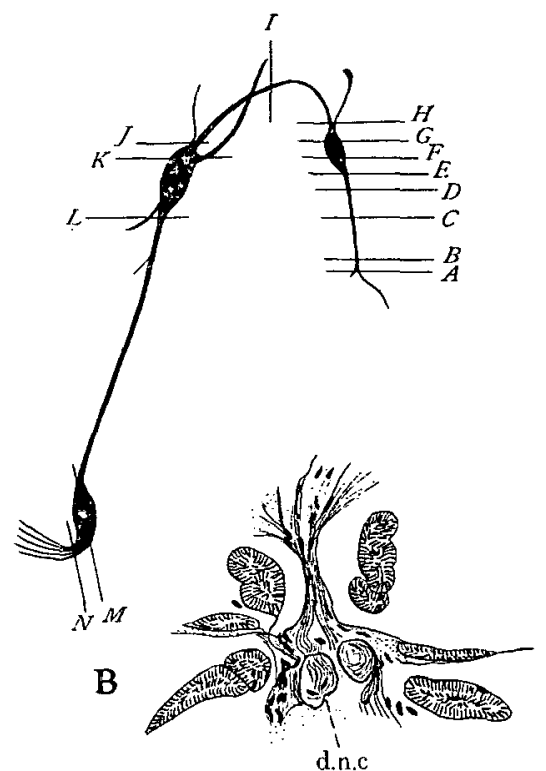

A

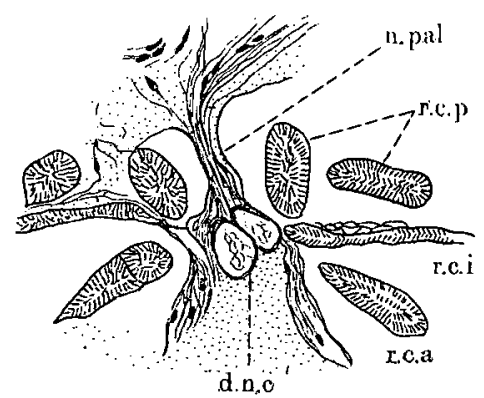

Fig. 15. Cross sections of nerve cord at different levels $(A-N)$ designated in a figure at the right-handed upper corner. Lettering as on p. 278. $($ All $\times 210)$

the other larger main cord bends abruptly upwards and soon further downwards to enter into the discal portion of the mantle. The final course of this larger cord, which I propose to name the pallial nerve (n.pal), could not be traced, but presumably it is identical with the antennular or peduncular nerve of ordinary cirripeds. 
In Cryptophialus minutus and Trypetesa lampas, however, the similar nerves pass backwards in separate lines from the beginning, as usual in ordinary cirripeds (BERNDT, 1903a, 1907). In these respects, all the offshoots from the cerebral ganglion in the present acrothoracican seem to be quite unique.

Besides, BERNDT (1903a) recognizes in Trypetesa lampas two other pairs of nerves arising from the same ganglion, one of which is as strong as the 'peduncular' nerve and the other is smaller; the former, according to him, does not correspond to anything of ordinary cirripeds, but the latter may be the 'optic' nerve, though it is devoid of any optic ganglion. In Cryptophialus minutus, however, he did not detect any trace of such nerves except a pair of the peduncular
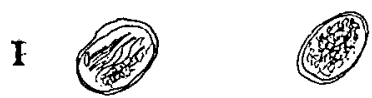

J

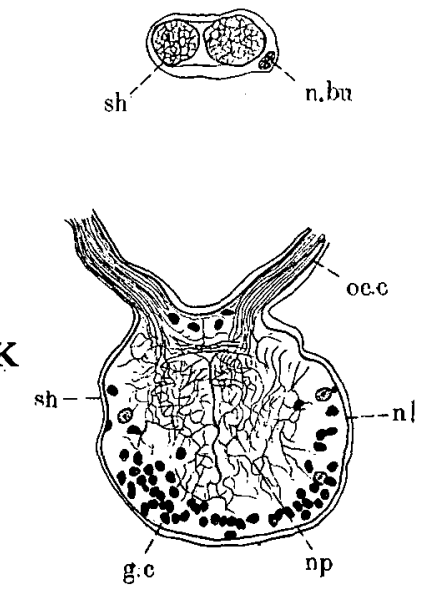

Fig. 16. Explanation is given in fig. 15. Roman numerals show the nerves running to the respective cirri. Other lettering as on p. 278 . [All $\times 210$ ]

nerves. As to the nature of these additional nerves, if any, his observations seem to be by far from the evidence which I have detected in the present acrothoracican; for the present it is impossible to explain what they are, unless his materials are directly examined.

The oesophageal commissures (oe.c) originating from the cerebral ganglion run upwards and forwards immediately around the oesophagus, branching off on the way a slender lateral nerve ( $n . l a t$ ) with an upper and a lower branchlets and then bend abruptly downwards just above the first transverse muscle $\left(t_{1}\right)$. They further pass forwards and downwards and finally unite with the fused infra- 
oesophageal ganglion (g.i). A little way before entering into the latter, another lateral nerve is arisen to the proximal region of the oesophagus. This oesophageal nerve (n.oe) always turns like a S-figure at the beginning and then branches into a number of branchlets, penetrating into the epidermal layer of the oesophagus through the ring muscles surrounding it (Fig. 17).

The infra-oesophageal ganglion ( $g . i$ ) lies below the buccal region inside the bases of the mouth-cirri, being inserted between the maxillary glands of both sides. The ganglion is very large, ovoid and bears no external indication of

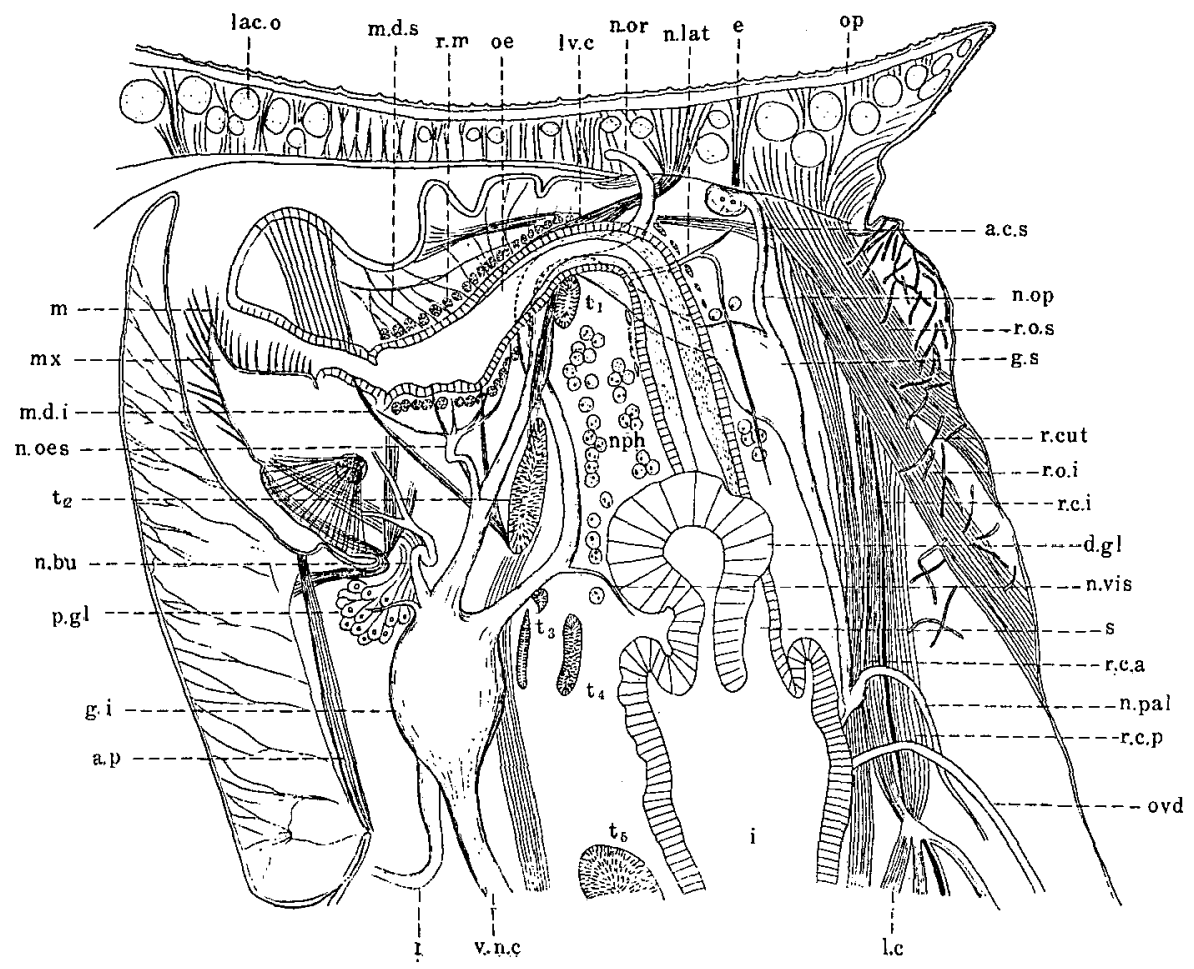

Fig. 17. Main internal structure of cephalic portion of body and its surroundings, partly schematic. Lettering as on p. 278.

dividing into two lateral lobes. From behind and below the commencement of the oesophageal commissure, there arises on each side a strong nerve which is as wide as the commissure; this nerve passes upwards behind the second transverse muscle $\left(t_{2}\right)$ and between the commissures of both sides, and runs further in front of the first transverse muscle $\left(t_{1}\right)$ up to the corium of the operculum, and terminates to a blunt end. This nerve undoubtedly corresponds with the adductor nerve in ordinary cirripeds, but because of the lack of the real adductor muscle in this acrothoracican it may be named the orificial nerve (n.or). This 
orificial nerve sends posteriorly a small branchlet towards the digestive glands (n.vis).

Immediately in front of the commencement of the oesophageal commissures there are two pairs of nerves, a smaller anterior one running to the periphery between the bases of the mouth-cirri and the other larger posterior one running to the buccal mass; hence the former may correspond with GruveL's 'nerf tégumentaire' (n.teg) and the latter with his 'nerf buccale' (n.bu). The arrangement of these buccal nerves is somewhat different from that in ordinary cirripeds and the number is smaller. These two nerves are really two branches of the direct offshoot from the oesophageal commissure, instead of being from the ganglion itself, as clear from Fig. $16 \mathrm{~J}$.

Furthermore, there are a pair of strong nerves, running from the lower portion of the ganglion towards the mouth-cirri, one on each side; this nerve is named as the first cirral or pedal nerve (Fig. $16 \mathrm{~L}$ and $17, I$ ). Therefore it is undoubted that this large ganglion lying below the buccal mass is the infraoesophageal and first thoracic ganglia fused together in a single mass.

The succeeding ventral nerve cord (v.n.c) runs for a long distance along the ventral side of the body. It is seemingly a single nerve cord, but on examination on cross sections it can be defined to be formed of two parallel cords closely united and coated together with a common sheath like the dorsal nerve cord. Only a pair of tegumentary nerves (n.teg) arise from this cord, a little way down the infra-oesophageal ganglion.

In the narrowed posterior portion of the body, the nerve cord forms a large ganglion, i.e. the terminal ganglion ( $g . t)$. This ganglion is oval in outline and a little smaller than the infra-oesophageal ganglion. From its ventro-lateral sides arise five pairs of strong nerves running respectively to the terminal cirri from the second to the sixth (II-VI). The ganglion itself exhibits no trace of being formed of ganglionic mass or lateral lobes, but the circumstance here presented may prove that it is in reality formed by the complete fusion of five thoracic ganglia, belonging to the third to seventh thoracic segments.

Generally speaking, the thoracic ganglia of this acrothoracican resemble those of the sessile cirripeds in the complete fusion of paired ganglia to a single mass, while the main nerve cords are more like those of the pedunculate cirripeds in their lengthiness and the formation of double chain, though closely united and coated with a common sheath. On the other hand, a feature that a pair of the peduncular or pallial nerves are closely connected for a long distance and coated with a common sheath as in the ventral nerve cord may be peculiar to this acrothoracican alone.

Histolosy. Concerning the histological structure of the nervous system, BeRnDT (1903a, 1907) has given detailed accounts for Trypetesa and Cryptophialus, so that not much need be added. Some remarks regarding the present material, however, may be necessary. 
The nerve cord is, as shown in any section, divided into three parts: The first part is the neurilemm (Fig. $16 \mathrm{~K}, n l$ ) where the thin cuticular outer layer encircles the nerve cord, the second is the ganglionic cell-masses ( $g . c$ ) where numerous nerve cells are crowded in the dorsal regions of the ganglion, and the third is the neuropile $(n p)$ where a great deal of nerve fibres pass through from end to end.

Cross sections of either of the central ganglia or of the nerve cord indistinctly indicate the general appearance being formed of a central core of fibres surrounded by densely packed nerve cells. In the supra-oesophageal ganglion, the ganglionic cells are aggregated together towards the distal (downwards in situ) and lateral regions, and the central mass of fibres unites across the middle line (Fig. 15F-G). In the infra-oesophageal ganglion, the ganglionic cells are rather more numerous on the ventral side than on the dorsal side (Fig. 16K), while the terminal ganglion shows the manner opposed to the above (Figs. $16 \mathrm{M}$ and 25).

The central body of the ganglion is filled with fine network of nerve fibres uniformly, though more or less aggregated into two lateral masses or neuropiles (LEYDIG's 'Punktsubstanz'). The central fibres continue with the nerve cord of fibrous structure. In the connective tissue between the neuropiles I could not detect any finer structure.

The ganglionic cells are more or less variable in size. Gruvel and BerndT recognize two types called as 'cellules geantes' and 'cellules ordinaires', the former of which in Trypetesa is, according to BERNDT, about $4 / 3$ to 2 times as large as the latter. However, I could not differentiate such two types so definitely in this acrothoracican. The neurilemm consists of a simple cuticular layer surrounding the whole nervous system and is further coated with a common sheath all throughout. The outer sheath is not shown as such a fibrous network of thickened layer as in Cryptophialus minutus, but only as a rather thin covering.

SEnse organ. There remains to be described the sense organ or eye. All earlier authors have not described about the eye or optic ganglion in the anatomical studies of the Acrothoracica. KüHNERT (1934) also, in her study on the larval development of Trypetesa lampas, did not pursue the final fate of the nauplian eye during metamorphosis. So it is of much interest to report here the presence of very developed eyes in this acrothoracican.

The eyes (Figs. 18 and 19, $e$ ), as has been alluded before, are situated at the same position as in ordinary cirripeds, that is, lying a little above the cerebral ganglion, buried wholly within the connective tissue just beneath the operculum. The upper margin of the eye is closely attached to the horizontal layer of fibrous structure which bounds the operculum proper belonging to the mantle from the cephalic region of the body.

In living state, the occurrence of the eyes is easily perceivable through the epidermis as a refulgent golden body embedded within each valve of the oper- 
culum, surrounding by the violet-blue pattern lying towards the dorsal (rostral) side (UTinomi, 1957, p. 7).

In longitudinal section (Fig. 19B), the eye (e), together with the optic nerve ( $n . o p$ ), originating from the cerebral ganglion, is shaped like a stick-head, its terminal end being bent towards the ventral (carinal) side. In horizontal cross section (Fig. 19A), it shows a close resemblance to that of Balanus eburneus (FALES, 1928), suggesting a highly developed feature for the group. It consists of two main parts, an outer covering which is modified from the connective tissue and an inner body of the true eye; the former measures about $90-97 \mu$ in

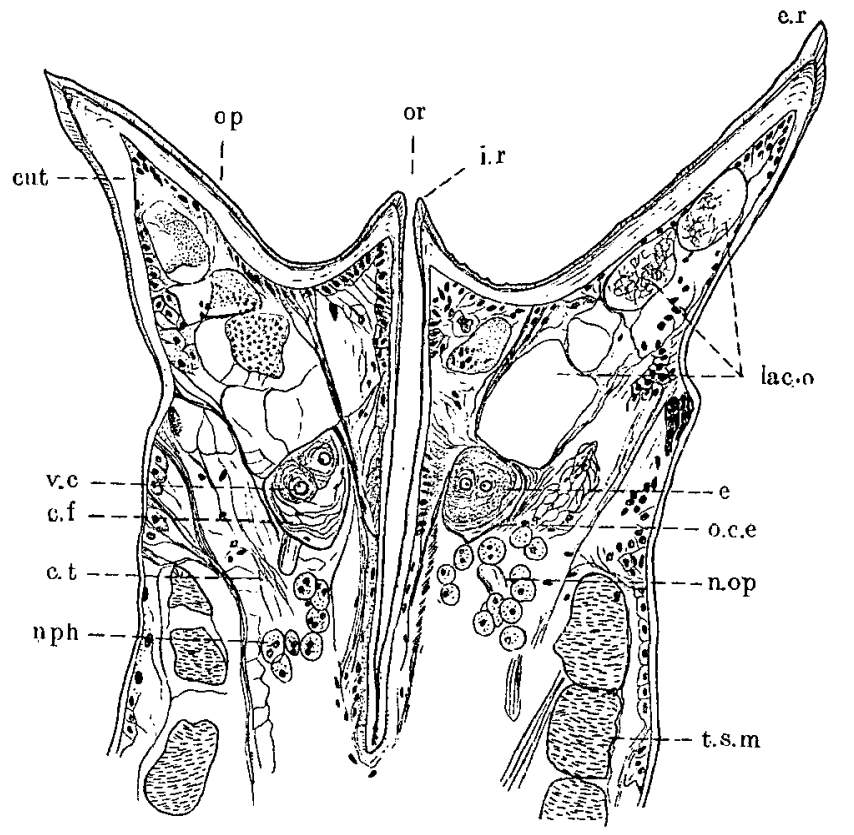

Fig. 18. Frontal section of operculum through eyes. Lettering as on p. $278 .[\times 150]$

longest diameter and about $53-60 \mu$ in shortest diameter, and the latter is about two-thirds as large as the former or more.

The outer covering (o.c.e) is shown as an ellipsoidal sac embedded in the cavity of the connective tissue of the body and separated by a rather thick layer of fibrous structure from the surrounding tissue, though not so intensely pigmented as in Balanus eburneus. Inside the outer layer, the inner body of the optic ganglion lies along the upper side, and the interspace between them is furnished with loose connective tissue fibres $(c . f)$, supporting the inner body to the outer covering; these fibres are apparently somewhat parallel to one another and contain spindle-like nuclei here and there. 
The inner body, i.e. the optic centre is strongly eosinophilous and apprently consists of two parts, each of which contains in its centre a large rounded nucleus, about $9 \mu$ in diameter. These two divisions may represent the two visual cells (v.c); the optic nerve coming from the cerebral ganglion passes through the outer layer and then becomes to divide into two separate cords ending to

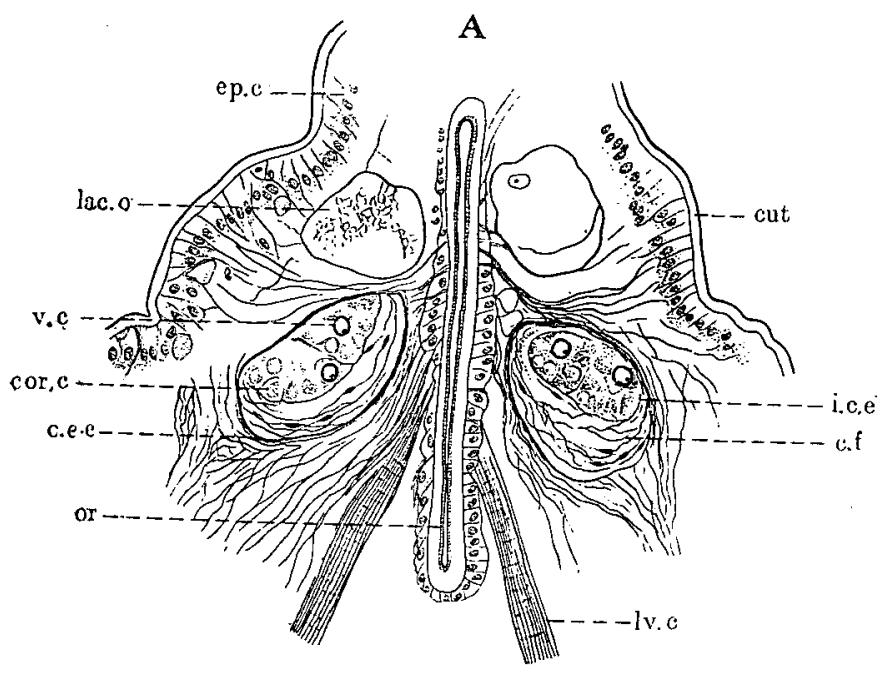

B

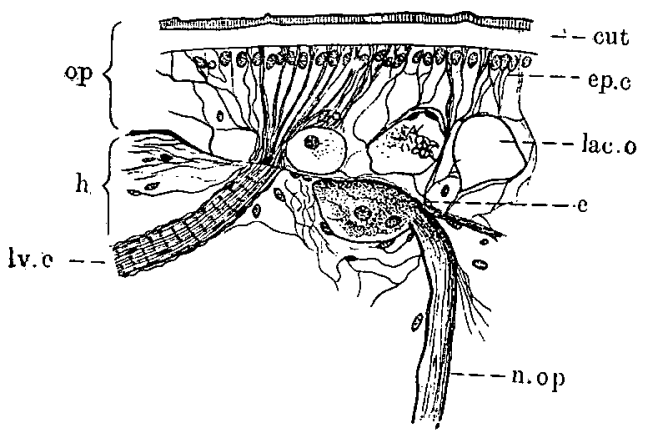

Fig. 19. A, horizontal section of operculum through eyes (Section-plane is slightly oblique to horizontal plane.) B, vertical section of operculum through eye. Lettering as on p. 278. (All $\times 210$ ]

the visual cells. The accurate outline of these visual cells could not be traced but a number of nuclei of the cortical cells (cor.c) could be traced around them. Any reticular structure could not be defined in the rest of the eye.

As mentioned above, the eye of this acrothoracican is highly developed in structure, not less than that in higher group of the Cirripedia. According to 
FALES, both the outer and inner coverings of the eye in Balanus eburneus are composed of a single layer of unpigmented cells in the area facing outwards, while those situated in the bottom are so pigmented that may be "either protective or reflective in nature".

In this acrothoracican, however, such specialization could not be defined, yet no supporting reticular connective tissue is inserted between the inner and outer coverings in the upper region which faces outsides through the opercular tissue (Fig. 18). Therefore, it may be supposed that the eye is similarly functional as a light-receptive organ. This is supported also from the behavior of living animal, as was mentioned in my first report (UTINomi, 1957, p. 20).

\section{Muscular System}

The muscular system of ordinary cirripeds has been studied in detail by Nussbaum (1890), but that of acrothoracicans is imperfectly known. In the following, the terminology of muscles are largely followed him in view of their homologies.

The muscular system of this acrothoracican may, for convenience sake, be divided into five categories: the mantle and its derivatives, thoracic body, cirri, buccal mass and digestive organ. The muscle appended to the last one have already been described under the same heading (See pp. 225-234).

Mantle ANd its DeRivatives. The muscular system of the mantle (Fig. 20) is very peculiar like other acrothoracicans in the total absence of any calcareous plates, but it is not essentially different from that of the nude pedunculate group of ordinary cirripeds.

The mantle-sac is lined within by two layers of muscles, an inner transverse and a medial longitudinal, and also by the outer layer of elastic fibres. As clearly shown in cross section (Fig. 21), there is a double series of lacunae (lac) in the coarse connective tissue between the outer and inner cuticular coverings (cut.e; cut.i) everywhere. The connective tissue between the lacunae is formed of bundles of elastic fibres (c.f) which expand inwards and outwards in a fanlike manner, connecting the inner and outer cuticular coverings. These formed in the discal portion of the mantle are much larger and stronger than elsewhere (Fig. 34). Inserted between the outer and inner lacunae, there occur many strong longitudinal muscles $(l . m)$ which do not reach quite up to the operculum; these muscles become longer towards the dorsal side opposite to the disc (Fig. 20). The discal portion only lacks the longitudinal muscles and its lateral edges provide the base of attachment for these muscles running along the sides. Under these longitudinal muscles, there are somewhat weak transverse muscles $(t . m)$ running parallel to one another from the lateral edges of the disc, about a little more half way around the sides; their distal one-third is, however, running 
outside the longitudinal muscles, turning their way to the exterior and blindly ending. These transverse muscles may be homologous with the ring muscles encircling the peduncle of ordinary pedunculate cirripeds. The lacunae lying outsides are generally numerous and capacious in the dorsal half of the mantle, while those lying insides are numerous and capacious in the ventral half.

Externally to the longitudinal muscles, there are fine elastic fibres (Fig. 20, r.e.f) arising radially from the uppermost knob of the attachment-disc; they are

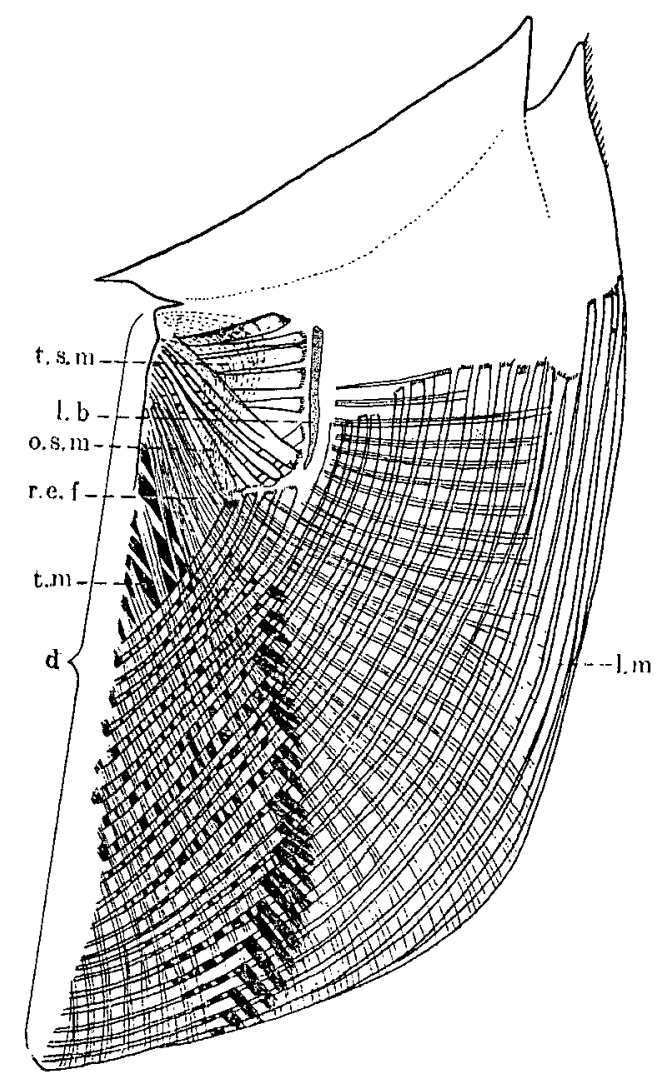

Fig. 20. Muscular system of mantle-sac, partly schematic. Lettering as on p. 278.

somewhat strong at the beginning but become faint gradually, so that they cannot be said as true muscles. Probably these outer radial fibres may correspond with the oblique muscles of the peduncle in ordinary pedunculate cirripeds. The gentle 'swaying' movement and the more powerful contraction may be performed by aids of all these muscles and fibres.

Besides, there is a group of short peripheral muscles on each side at the upper portion of the mantle-sac near the discal edge. It consists of two layers 
of short muscles, an outer oblique and an inner transverse, sent from the uppermost knob of the attachment-disc (Fig. 20). The inner transverse muscles (t.s.m) are formed of 4-7 bundles and their distal ends come into contact with the chitinous lateral bar ( $l . b)$ which corresponds with DARwIN's 'horny bar' and BERNDT's 'Verdickungsleiste' as mention before. The outer oblique muscles (o.s.m) are formed of 5 to 7 bundles, running radially down to the upper ends of several longitudinal muscles lying close to the discal side. Apparently these short muscles may serve to support the whole mantle-sac tightly to the upper part of the attachment-disc (cf. UTINOMI, 1957, p. 10, fig. 4) and at the same time may aid the voluntary movement of contraction of the longitudinal muscles by

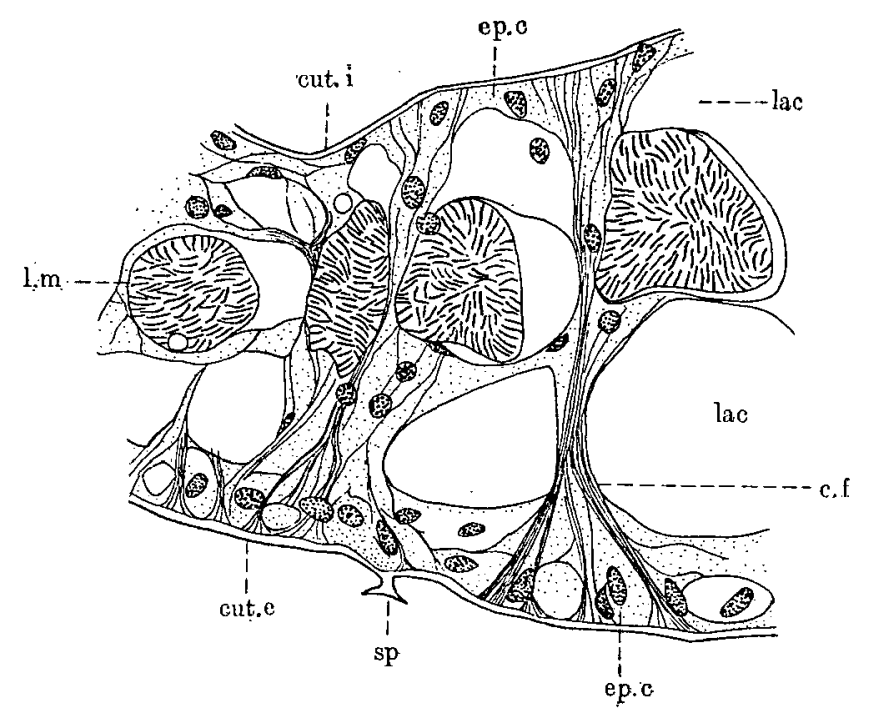

Fig. 21. Transverse section of a part of mantle. Lettering as on p. $278 .[\times 450]$

giving the fulcrum to the lateral bar. So they may be called the supporting muscles of the mantle proper. So far as I am aware, such muscles are absent in ordinary cirripeds, but presumably the outer ones are parts of the longitudinal muscles, as interrupted in the middle and the inner ones are parts of the transverse muscles, as resulted from the formation of the lateral bar.

All these muscles surrounding the mantle-sac are issued from the base of the attachment-disc all throughout. In yonger stage before the disc is formed, they on both sides are attached to one another along the medial line at the dorsal side of the mantle, but as growth proceeds on, they become separated widely except for the uppermost end of the disc, i.e. the upper knob; no other muscle is found in the periphery of the mantle.

Near the dorsal side of the orifice a pair of remarkably powerful muscles, 
(r.o) are attached, uniting together in a medial line to the thickened roof of the operculum (Fig. 17). This muscles run obliquely downwards to the disc, diverging into two large bundles, one is named the retractor orificii superior (r.o.s) and the other the retractor orificii inferior ( $r . o . i)$; both of them attain the medial line of the disc above the middle of its whole length. A similar muscle has been described by Aurivillius (1894) in Lithoglyptes indicus too. This muscle may correspond to BERNDT's 'Sehne des Retractor orificii' in Cryptophialus minutus. In the present Berndtia, however, the outer membrane of the mantle along which this muscle runs is never thickened nor chitinized, but on the contrary the muscle itself is more powerful. Its action would be to draw down the whole body within its own mantle cavity and also to shut up the orifice by its own contraction. But when it relaxes, its elasticity will push out the dorsal end of the operculum and in consequence the orifice will be opened by expanding the membranous orificial velum on the opposite side (cf. UTINomi, 1957, pp. 8-10 and fig. 4,o.v).

In addition to this muscle, BERNDT points out the presence of another pair of muscles named 'dilatatores orificii' acting antagonistically to the retractor; according to him, this muscle is attached on each side to the inward fold at the opposite (ventral) end of the orifice, and its contraction would cause the orifice to open. DARwIN also recognized a similar muscle as occurring in Trypetesa lampas, whereas Berndt and Genthe did not.confirm its presence. Concerning the so-called 'dilatator muscle', TomLinson's recent works on different species of Trypetesa and Cryptophialus (1953, 1955, 1960) are, unfortunately, insufficient to settle this point.

INTERNAL ANATOMY OF OPERCULUM AND DISC. In connection with the above account, some details of minor structure of the mantle which were not referred to before should be mentioned.

As mentioned already, the connective tissue of the operculum is distinctly separated by a horizontal layer of fibres from that of the cephalic region of the body itself. The epidermis of the operculum is coated with a cuticular layer, about $15-18 \mu$ thick in its upper surface, where the cuticular covering is the thickest. The cuticle consists, as usual, of two layers, the outer layer being thin, yellowish and transversely striped and the inner layer being thick, white and quite smooth. It is supported by a thick epidermal layer of cylindrical cells between which fine elastic fibres are inserted; these fibres are here and there grouped together and connect the external cuticle with the boundary between the operculum and body proper; some of them lying towards the dorsal (rostral) side are continued from the muscles of the body proper, such as the retractor orificii and levator capitis (Figs. 17 and $19 \mathrm{~A}-\mathrm{B}$ ).

The interior of the operculum is apparently soft and filled with a number of large sac-like or canalicular lacunae between the loose connective tissue fibres 
(Fig. 18, lac.o). These lacunae vary in size and shape according to their location, but generally globular or ovoid in section. Sections show that they are either granular or reticular, or else wholly empty.

In the discal portion, the cuticular coverings are made of many layers, particularly in the upper part. These cuticles are sometimes broken into numerous chitin-fibres like shavings and remain entangled and buried deeply in the underlying connective tissue of the mantle (Fig. 22). These cuticular fragments are yellowish all over and stained only with eosin.

Then, it may be asked why these cuticular fragments are formed. At each moult the continuous cuticle of the mantle and body must split along the line

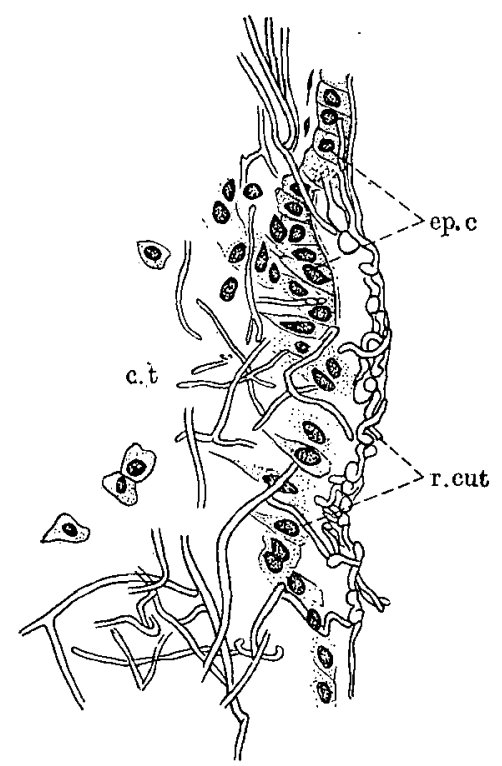

Fig. 22. Longitudinal section of discal portion of mantle. Lettering as on p. 278 . $[\times 420]$

around the attachment-disc, then the old cuticular coverings are cast off and replaced by the newly added cuticle. However, the portion of the disc is firmly cemented to the wall of the burrowed cavity, so that it is impossible to cast off the old layers under the disc at each moult. Accordingly, the old layers must be forced away from the new layers by their own disintegration, and thus such fragments of old cuticles still remain within the underlying connective tissue instead of being wholly cast off.

As exuviation repeats on, the disintegrated cuticles come to wander about within the connective tissue of the mantle and some of them may migrate towards the tissue of the operculum, probably due to the incessant movement 
and strong contractility of the body. Such a curious phenomenon is probably not peculiar to this acrothoracican only, but, if thoroughly examined, may be observed in other acrothoracicans. Indeed, a similar phenomenon has already been observed by BRINKMANN (1936) in two examples of the Rhizocephala, such as Lernaeodiscus ingolfi and Triangulus munidae.

Bopy. The muscles of the body proper including the head and thorax are numerous, powerful and very complicated in arrangement.

Like the other acrothoracicans, the prosoma is much prolonged in comparison with ordinary cirripeds and the succeeding thoracic segments are greatly compressed or fused, so that the muscular system is more or less different from that of ordinary cirripeds. The muscles of the body proper are generally divided into three kinds, the longitudinal or extensors, the oblique or flexors and the transverse ones. The first-named muscles are situated dorsally, while the second are ventrally, both being paired. The last ones run across the body along the median part. The general arrangement of these muscles is shown in Fig. 23 somewhat diagrammatically.

First of all, the body is supported to the mantle by the retractores corporis arising from the upper end of the retractor orificii on the roof of the operculum. This muscle runs downwards to connect with the uppermost end of the dorsal side of the body. It is composed of three pairs of groups, the retractor corporis posterior (r.c.p), retractor corporis intermedius ( $r . c . i)$ and retractor corporis anterior (r.c.a). Of these, the posterior one is made up of four large bundles on each side, lying in a transverse row, while the anterior one is two on each side, lying diagonally and somewhat weaker than the former. The muscles of these two groups on both sides are perfectly separated by a thin interjacent mesentery which is formed of a pair of strong, dorsoventrally depressed muscles and their fibrous continuations ( $r . c . i)$, so that the posterior muscles ( $r . c . p$ ) lie in the mantle and the anterior ones (r.c.a) in the body itself (Figs. 15 A-B and 23).

Besides, from the upper end of these muscles two or three pairs of muscles run towards the lateral sides of the head; these muscles may correspond to the attrahens primus, secundus and tertius in ordinary cirripeds and act as protrusors of the body (Fig. 23, p.c).

Further downwards, the remarkably powerful longitudinal muscles run along the dorsal side of the body to the posterior end; the main bundles of those are in the proximal portion massed together close to the dorsal side, and then run separately along the dorsal side, and then run separately along the dorsal and lateral sides. These longitudinal muscles, as can be detected only by cross sections, are made up of apparently five large bundles crowded together on each side. Of these, the three larger bundles, namely the longissimus primus $\left(l_{1}\right)$, secundus $\left(l_{2}\right)$ and tertius $\left(l_{3}\right)$, are sometimes closely united so as to form a secondary large bundle, and the smaller two, namely the longissimus intermedius 


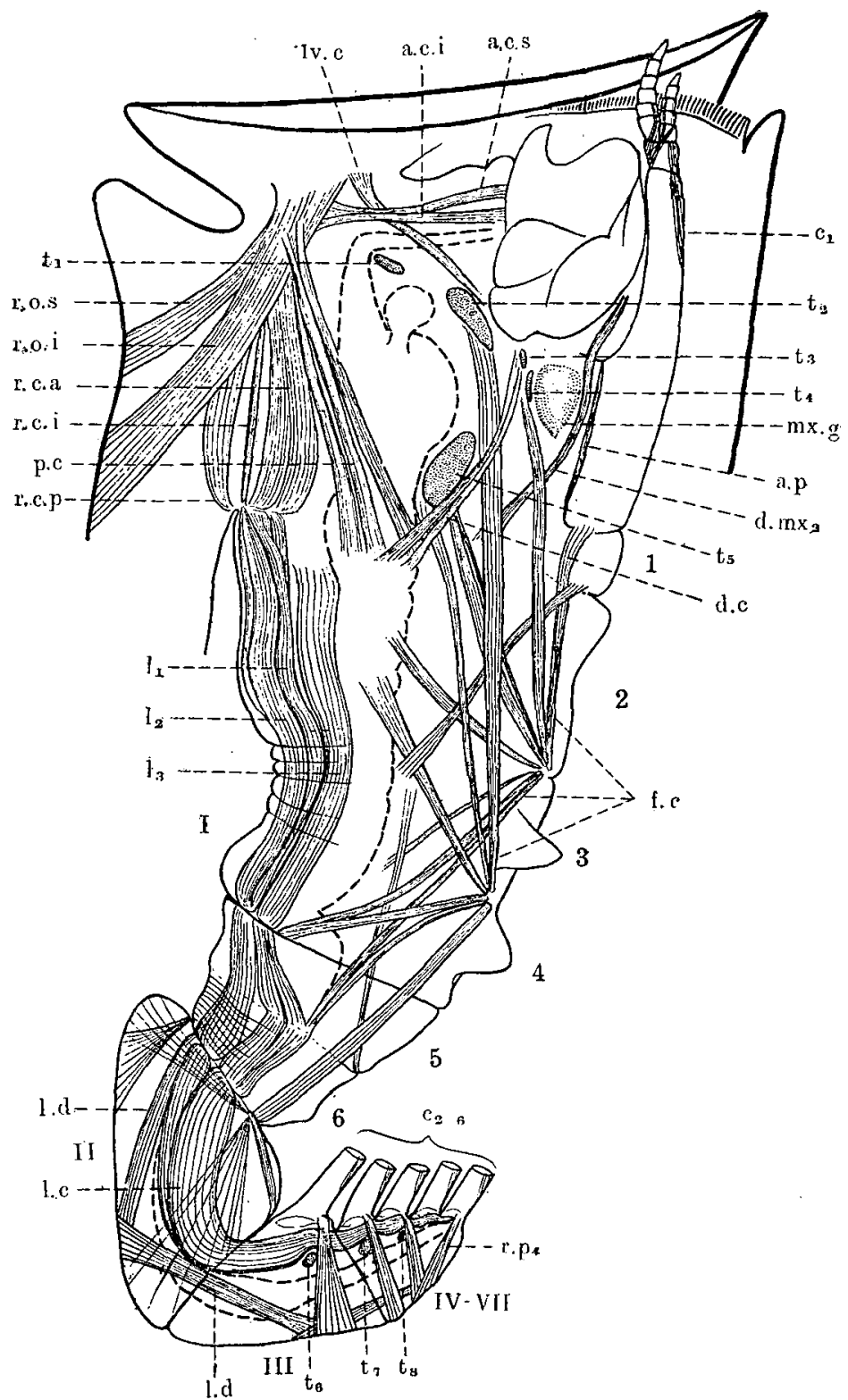

Fig. 23. Muscular system of body, schematic. Roman numerals show the number of thoracic segments and arabic numerals the number of pseudosomites. Broken line indicates the outline of alimentary canal. Other lettering as on p. 278. 
(l.i) and dorsalis (l.d), are usually separated from each other (Fig. 24). These muscles are, however, never continuous throughout the whole length, but interrupted on the way at two points of articulation, that is, between the fourth and fifth pseudosomites and between the first and second somites. Perhaps this might be formed to strengthen the power of contraction, because they are too long to contract themselves and also to attract the flexor muscles on the ventrolateral sides.

In the terminal portion of the thorax from the second to the fused terminal segments, the longissimus dorsalis on each side is widely separated from the remaining longitudinal muscles and articulated at the middle of the dorsal wall of each segment (Figs. 23 and 33). The action of this muscle is to retract the adjoining segment, as it acts as antagonists to the other continuous longitudinal

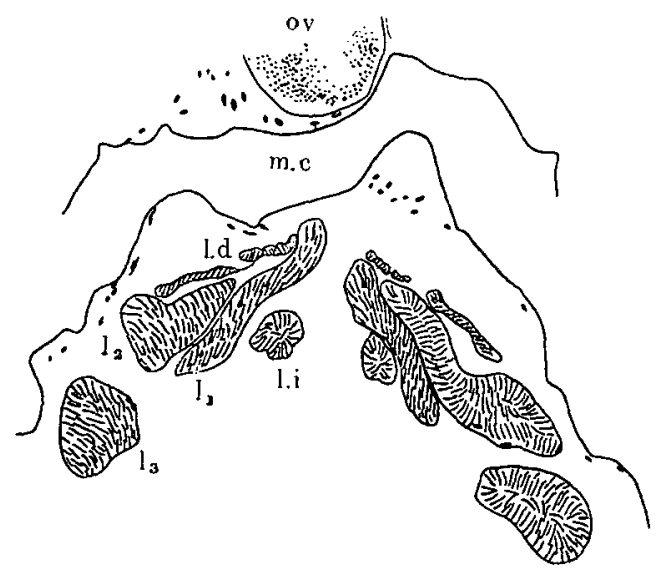

Fig. 24. Transverse section of the proximal part of first thoracic segment, showing the arrangement of dorsal longitudinal muscles. Lettering as on p. 278.

$(\times 210]$

muscles; the latter muscles running along the ventral side serve to extend the terminal portion of the body (Figs. 23,25 and 26 ).

Turning back again to the head portion, there are three pairs of remarkable oblique muscles which connect the buccal mass with the dorsal side of the operculum; they are of similar strength and finely striated. Two of them arising from a little below the base of the retractor orificii run ventrad to the mouth along the oesophageal tract; one lying upwards which may be named the adductor capitis superior (a.c.s) terminates to the dorsal roof of the labrum behind the crest-like projection, and the other lying downwards which may be named the adductor capitis inferior (a.c.i) terminates to the underside of the ring muscles surrounding the beginning of the oesophagus, diverging like a fan. 
The remaining one (l.v.c), originating from the front of the eye below the operculum, passes between the pairs of the above-mentioned two muscles down to the basal articulation of the buccal mass; this muscle may correspond to the levator capitis in ordinary cirripeds (Figs. 23 and 28).

As already mentioned, when the cirri are extended out of the orifice, the

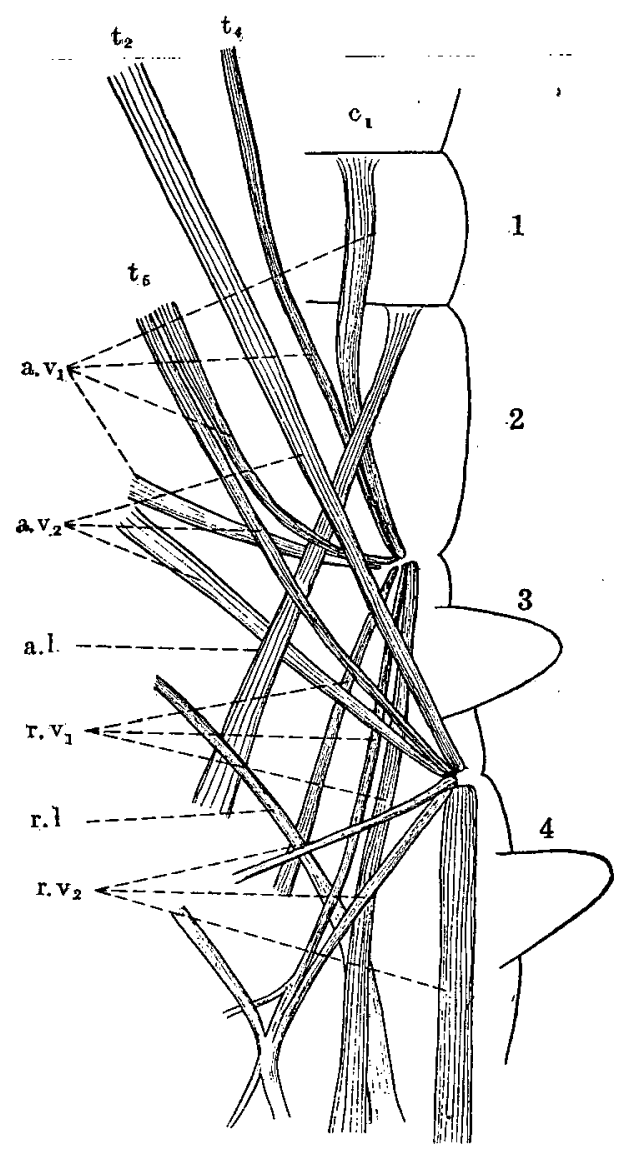

Fig. 25. Arrangement of ventro-lateral flexor muscles of body proper, schematic. Arabic numerals show the number of pseudosomites. Other lettering as on p. 278.

head must be compressed in order to widen the mantle-opening. So, when the former two muscles contract, the buccal region will be pushed dorsad, and when they relax, the elasticity of the latter muscle will resume its shape. Besides, there is a muscle which is attached to the lowermost end of the buccal region and passes obliquely downwards; this may act as the depressor capitis (Fig. 28, d.c). 
As shown in Figs. 23 and 27, which have been drawn from a number of total preparations, the muscles occurring on the ventrolateral side of the body are made up of two complexes of flexors $(f . c)$. These flexor muscles are radially arranged on each side and converged at two points, one between the second and third pseudosomites and the other between the third and fourth ones. In each one, the muscles generally consist of 6 or 7 bundles, which can be distinguished functionally into the 'attrahens' and 'retrahens'; the one (a. $\left.v_{1-2}\right)$ are running downwards or upwards and the other $\left(r . v_{1-2}\right)$ backwards or downwards. In addition, there are two fiexor muscles on the lateral sides, running across the above flexors; one is named here the attrahens lateralis $(a . l)$ and the other the retrahens lateralis $(r . l)$. All these flexor muscles on the ventrolateral sides are more slender and shorter than the extensor muscles on the dorsal side. By the antagonistic action between these muscles of two kinds, the body is capable of contract itself and also of laterally twist or wriggle itself.

In the posterior thoracic segments, each carrying a pair of cirri, there is no flexor muscle but these segments bear each a powerful retractor muscle, attached to the base of the cirri, excepting the fith one, being four pairs in all (Figs. 28 and $\left.29, r . p_{1-4}\right)$. These muscles extend to the dorsal side, passing over the longitudinal muscles. When these muscles contract, the terminal cirri may become fully stretched. The so-called 'attrahens pedis' or 'retrahens pedis' usually found in ordinary cirripeds are not discriminated.

The transverse muscles connecting the body walls of both sides are eight in number, five lying in the anterior prosomal and three in the terminal thoracic regions (Fig. 23, $t_{1-8}$ ). The first one, transversalis $I\left(t_{1}\right)$ lies just below the point of curvature of the oesophagus and oesophageal nerve commissures. BERNDT (1907) refers the corresponding muscle found in Cryptophialus minutus to the 'adductor scutorum'. But it is inaccurate, since the adductor scutorum usually runs across the body dorsal to the oesophagus in ordinary cirripeds, except only the genus Ibla, and the scuta are lacking in acrothoracicans. In this acrothoracican, evidently this muscle does not serve for opening and closing the orifice, as can be inferred from its situation and its weak strength; here it does not attain the external cuticles on both sides, lying only in the body proper, diverging like a fan at both ends (Plate XXXI, Figs. 1 and 2).

The second transverse muscle $\left(t_{2}\right)$ is situated on the boundary between the buccal region and the head proper, along which the external cuticle is deeply grooved. It runs across the body through the oesophageal nerve-commissures and orificial nerves of both sides. From both the ends of this muscle, a number of muscles, such as the dilatatores oesophagi inferior, levator capitis and flexor corporis ventralis, spring upwards or downwards, as described above; the last one is remarkably powerful and extends posteriorly down to the second ventral muscle center. In cross section, this second transverse muscle is shown by an elongate to oval outline. 
The third transverse muscle $\left(t_{3}\right)$ lying beneath the second maxilla and behind the infra-oesophageal ganglion, is very weak, and apparently consists of two slender bundles. The fourth transverse muscle $\left(t_{4}\right)$, lying behind and a little below the third one, is weaker than the second but stronger than the third. The fifth transverse muscle $\left(t_{5}\right)$, lying at the same distance below the third one, is the largest of all transverse muscles. To both the ends of the muscles, from the second to the fifth, are attached one or two flexor muscles running obliquely posteriorly along the ventrolateral sides of the body (Fig. 23).

Further downwards, there lacks the transverse muscle for a long distance. But in the terminal thoracic segments carrying the cirri, three transverse muscles $\left(t_{6-8}\right)$ are present, one in the third, fourth and fifth segments respectively,

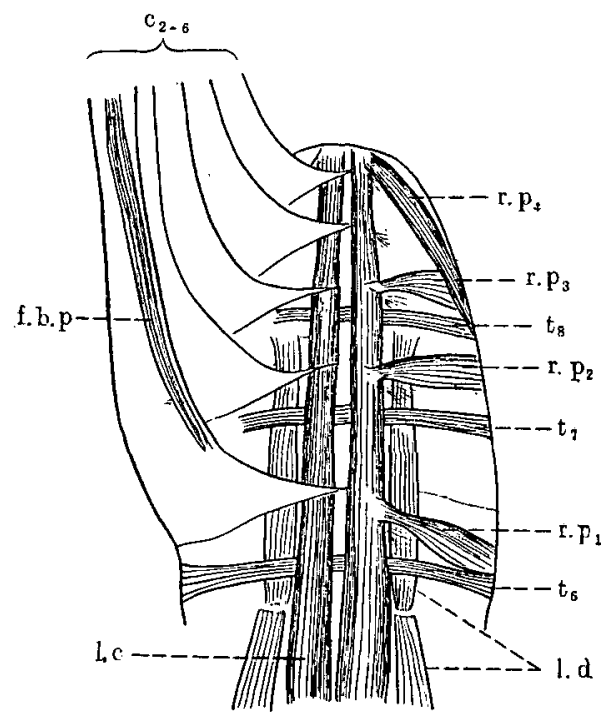

Fig. 26. Muscles of terminal portion of thorax in ventral view, schematic. Cirri on one side are removed. Lettering as on p. 278.

nothing being in the remaining terminal two segments. All of them traverse dorsally to the longitudinal muscles lying close to the ventral side; the anterior five transverse muscles mentioned above lie, on the contrary to the longitudinal muscles (Figs. 23, 26 and 27). As far as the arrangment of transverse muscles of the body is concerned, this acrothoracican is very different from ordinary cirripeds.

Buccal mass. Concerning the muscles of the mouth-parts in the Acrothoracica, there has been no detailed description. As far as I have confirmed, the muscular system of the buccal mass in this acrothoracican is essentially similar to that in ordinary cirripeds and rather more developed. 


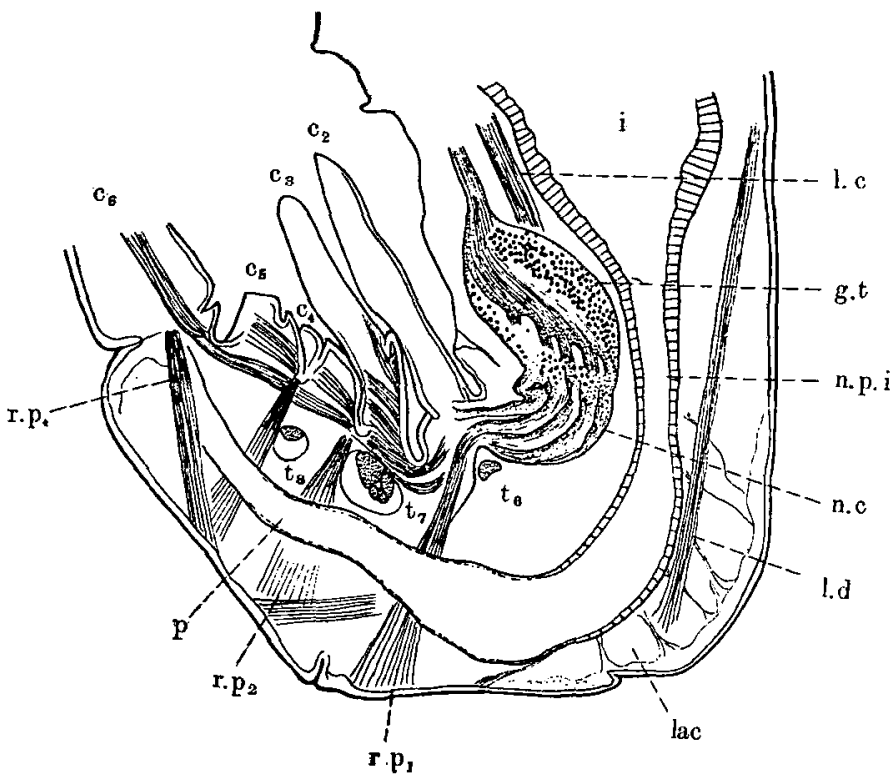

Fig. 27. Median longitudinal section of terminal portion of thorax. Lettering as on p. $278 .\lceil\times 100]$

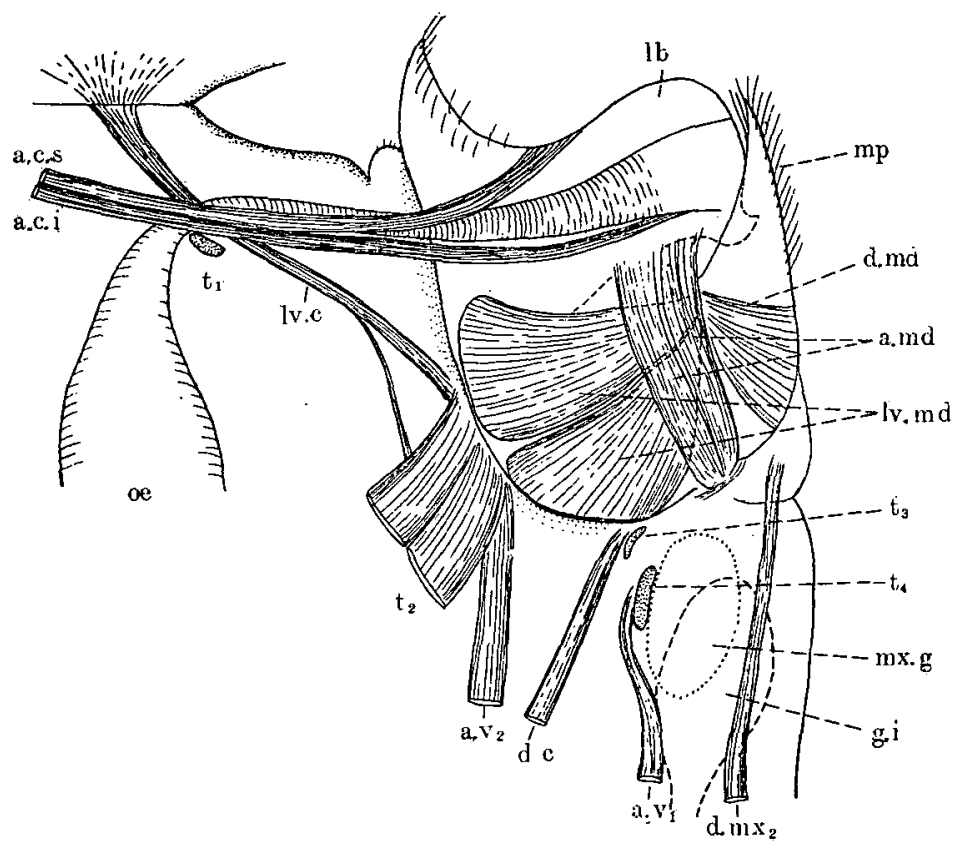

Fig. 28. Muscular system of buccal region and its surroundings, partly schematic. Lettering as on p. 278. 
Before going further, it should be noted that Darwin and Nussbaum seem to have an opposed view as to the nomenclature of the elevator and depressor muscles and also their function. But for the present I follow the latter author.

The mandible (Fig. 28) is furnished with five strong muscles one of which is the depressor (d.md), two the levator (lv.md) and two the adductor (a.md).

The depressor muscle, shortest of all these buccal muscles, is attached to the lower proximal end of the mandible and runs upwards, diverging like a fan and ends to the frontal edge of the mandibular palp. The two levator muscles, largest
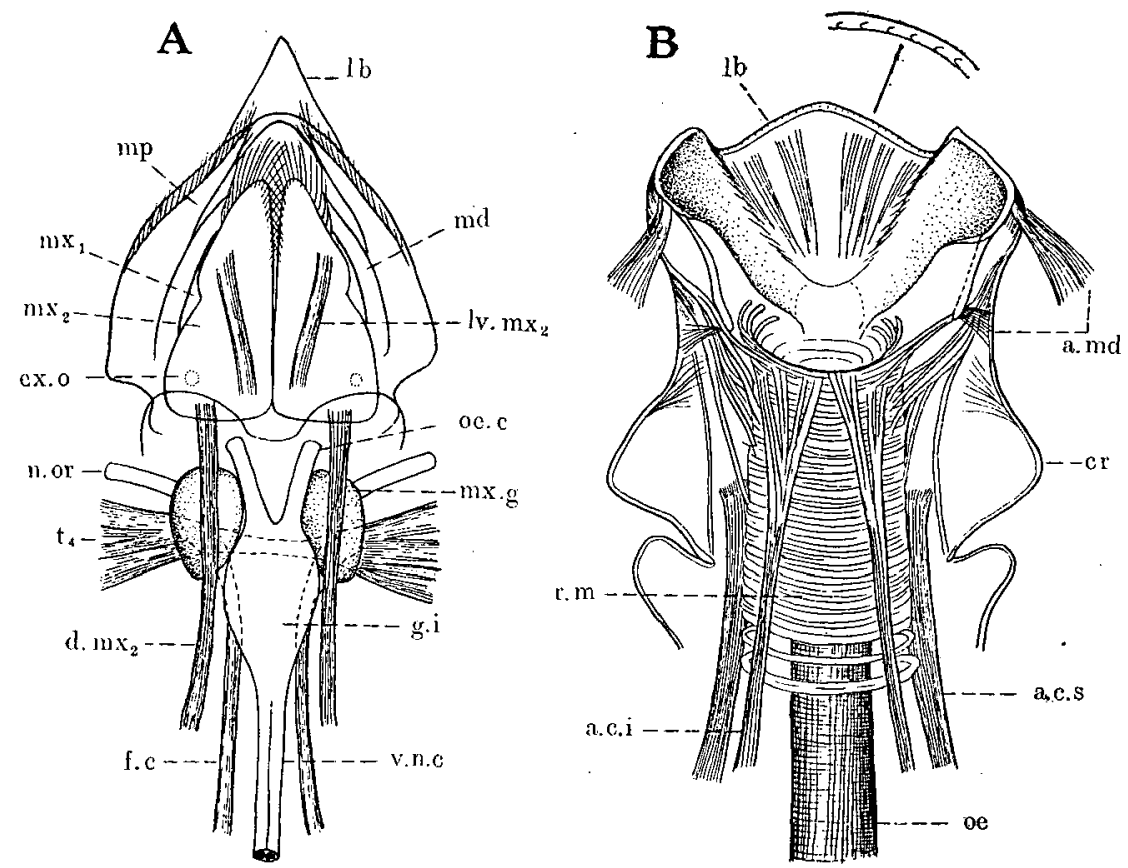

Fig. 29. A, Muscles and nerves at the base of mouth, in ventral view. B, muscles around mouth-opening and oesophagus, viewed from underside, partly schematic. Lettering as on p. 278.

of all buccal muscles, are attached to the point where the depressor muscle unites to, and run downwards side by side, spreading considerably out, and are attached at their broad ends to the basal articulation of the buccal mass. The two adductor muscles arising from the upper proximal end of the mandible run outside the levator muscles, crossing at right angles and extend to a slight lateral cavity of the labrum.

The first maxilla (Fig. 30) is furnished with six muscles consisting of one flexor $\left(f . m x_{1}\right)$, two adductors $\left(a . m x_{1}\right)$ and two levators (lv. $\left.m x_{1}\right)$, as in ordinary cirripeds. Besides there is a rigid and long apodeme ('maxillen style') ( $m x . s$ ) on the lower edge; it is shaped like a hockey-club and runs nearly parallel to the 
outer membrane down to the second transverse muscle lying at the basal articulation of the buccal region, and thus it serves as a support to the whole organ for movement. The arrangement of these muscles is similar to that of ordinary cirripeds. Of these the flexor muscles on both sides are considerably long and their lower ends are confluent at the middle of the second transverse muscle of the body.

The second maxillae (Figs. 29 A and 31) on both sides are connected together at their basal segment by a common fan-like adductor muscle $\left(a . m x_{2}\right)$ along the medial line. Attached to the fused basal segment, there are two strong muscles,

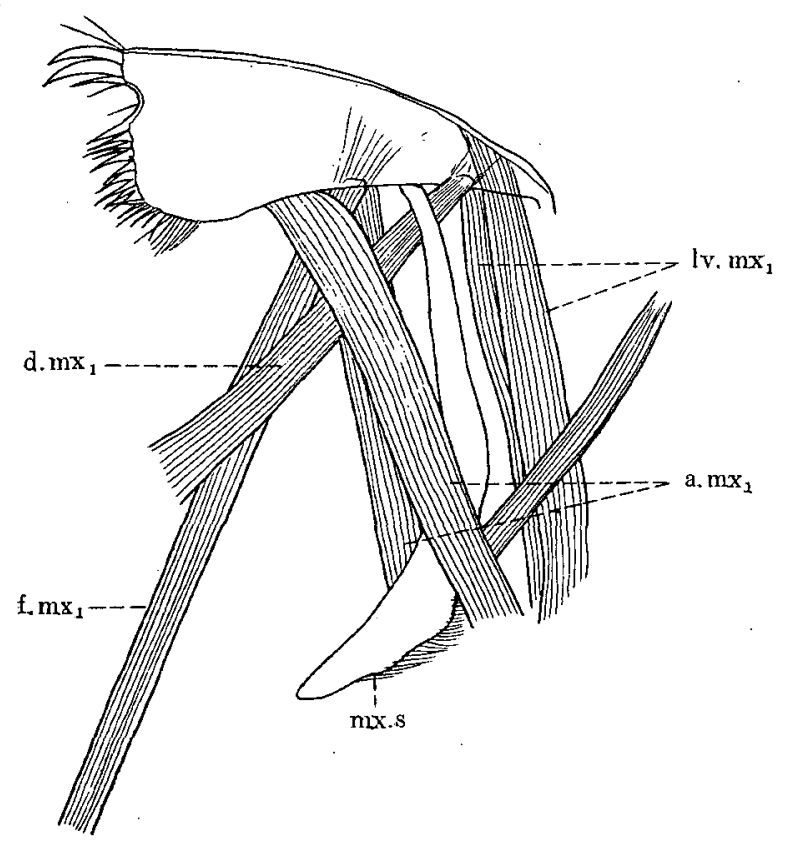

Fig. 30. Muscles appended to maxilla I. Lettering as on p. $278 .(\times 100)$

the upper one of which is the flexor $\left(f \cdot m x_{2}\right)$ and the lower one is the depressor $\left(\left(d . m x_{2}\right)\right.$. Inside the blade, a voluntary muscle runs longitudinally from the base of the lower lobe $(l . l)$ to the middle of the upper lobe $(u . l)$ lying close to the outer surface; this muscle apparently acts as a levator $\left(l . m x_{2}\right)$.

CIRRI. At first sight it may be supposed that the muscular system of the cirri might be similar to that of ordinary cirripeds. But it is not the case, since all the muscles of the cirri, such as the extensors and retractors, are not directly connected with those of the body itself. This is probably due to the wide separation between the mouth-cirri (the first cirri) and the terminal cirri (the 
second to sixth cirri), and to the pronounced prolongation of the basal segment of all the cirri.

In the first thoracic cirri or the so-called mouth-cirri (Fig. 32B), the basal segment of the protopodite is very prolonged and plump; the flexor muscle ( f.b.p) is rather short and attached at its upper end to the posterior (ventral) distal angle of the lower segment and extends a little way down to the posterior margin of the same segment. It is devoid of its own extensor muscle, but on the other hand the extensor muscle of the upper segment, i.e. the extensor intermedius (e.i) extends down within it. Both the flexor and extensor muscles do not extend far downwards beyond the upper one-third of the lower segment; in ordinary cirripeds, however, both extend down to the base of the lower segment

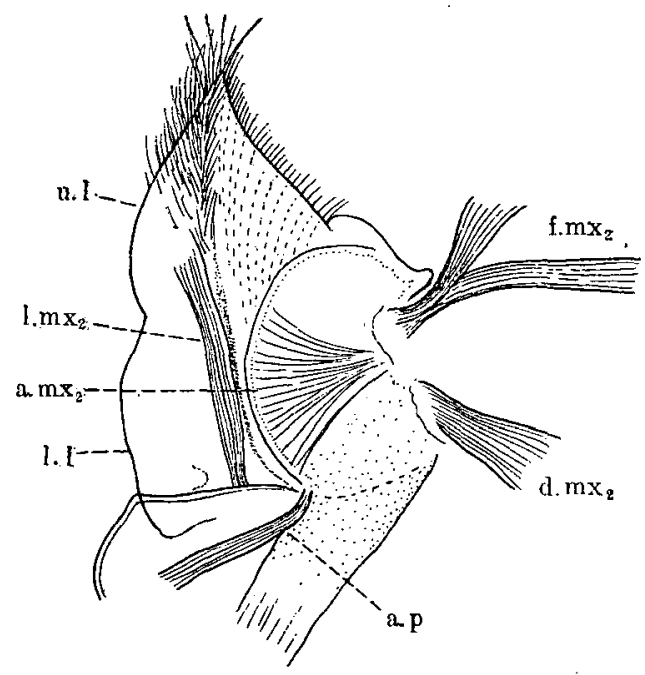

Fig. 31. Muscles appended to maxilla II. Lettering as on p. $278 .[\times 80]$

and connect with the adductor muscle of the cirri lying within the body itself. At its base there is a solitary muscle connecting the upper and lower ends of the base, lying vertically; this is probably equivalent to the 'adductor baseos pedis' in ordinary cirripeds (Fig. $23, a . p$ ), although it is according to Nussbaum lacking in the first cirri alone in the pedunculate cirripeds. Internally the lower segment is furnished with numerous elastic fibres running transversely to connect the dorsal and ventral outer cuticles. In the upper segment of the protopodite, the flexor muscle of its own (flexor intermedius) is likewise lacking, but on the other hand the flexors of both the rami (flexor cirri medialis and lateralis) are attached at their lower expanded ends to the anterior margin of the segment. Both the rami, however, lack the extensor muscle at all. 
The muscular system of the five posterior cirri is almost the same as that of the mouth-cirri, but somewhat different in minor points (Fig. 32 A). Firstly, at the base of the cirri from the second to the seventh, exclusive of the sixth one, there is a retractor muscle of the cirri $(r . p)$ respectively. They are attached to the inner angle of the base of the cirri and run obliquely forwards down to the dorsal side of the segments, where they are attached. No other muscle answering to the 'adductor baseos pedis' of ordinary cirripeds is found there.

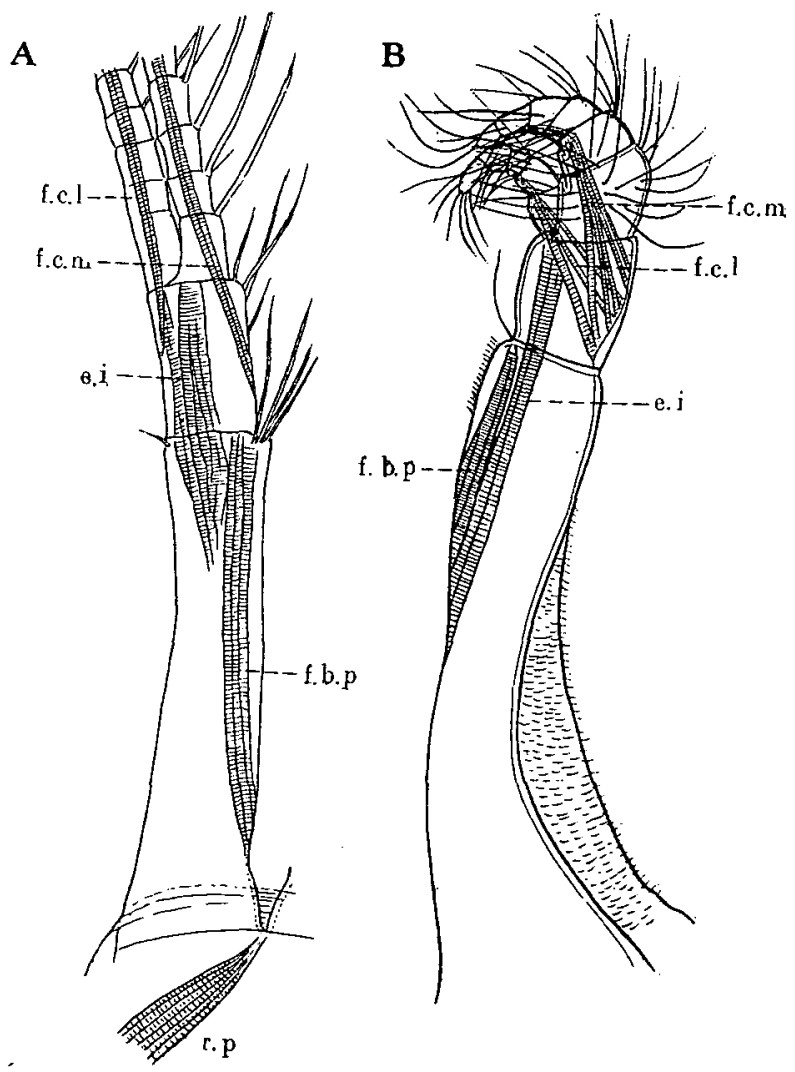

Fig. 32. A, muscles of a terminal cirrus. B, muscles of mouth-cirrus. Lettering as on p. 278. [All $\times 100]$

The flexor muscle of the lower segment of the protopodite is much longer than that in the mouth-cirri, but its lower end does not attain the base; hence there is no direct connection between it and the retractor muscle of the cirri. The flexor muscles of the rami are attached at their lower ends to the lower part of the medial (ventral) margin of the upper segment of the protopodite, instead of being to the dorsal margin. The extensor intermedius (e.i) is not so long as in the mouth-cirri and its lower end does not attain the lower end of the flexor 
baseos pedis (Figs. 26 and $32 \mathrm{~A}, f . b . p$ ). Neither the 'extensor baseos pedis' nor 'flexor intermedius' as called by Nusseaum is found, as in the mouth-cirri (Fig. 33).

Besides, in each segment of the rami there are short flexor muscles, which are branches of the main flexor muscle of the cirri to move the bristles.

As clear from the above account, it may easily recognized that the posterior cirri cannot be so much incurled as in ordinary. cirripeds, even when they are fully exserted_and expanded fully in .a fan-like net, and the mouth-cirri. cannot be protruded out of the orifice and thus do not serve for capturing prey. Also refer to my previous account on the cirral movement and feeding habit (UTINomi, 1957, pp. 19-23).

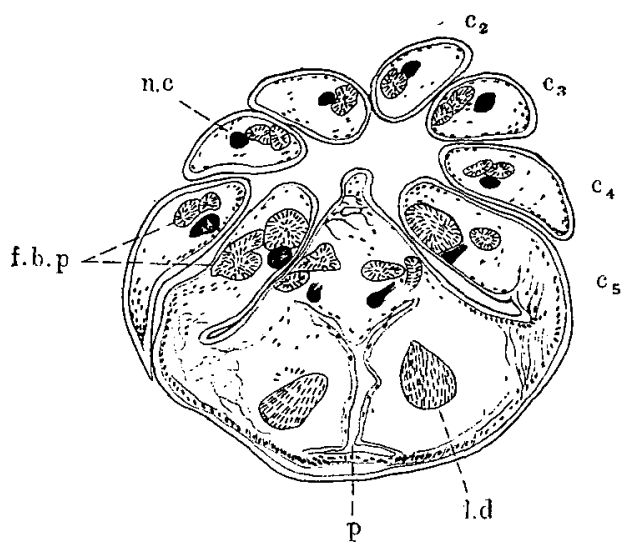

Fig. 33. Transverse section of terminal portion of thorax, showing the muscles and nerves running to cirri. Lettering as on p. $278 .[\times 100\}$

\section{Reproductive System}

TOPOGRAPHy. As in other acrothoracicans, the ovaries lie on the dorsal side of the animal, just under the thickened layer of the disc-formed mantle, filling up the lacunar cavity traversed by many strong fibres connecting the inner and outer cuticular coverings (Fig. 34, ov).

In young females, less than about $1.5 \mathrm{~mm}$ in length, the ovaries are generally not yet developed, but in still larger ones they become more distinct.

A somewhat developed ovary (Fig. $35 \mathrm{~A}$ ) consists of a greatly ramified tube containing the rudiments of ova or oocytes $(o o c)$. The ovarian tubes within the mantle are variable in 'size, being partly broad where are occupied by the ova and partly so narrow that may be difficult to trace' the whole tube. Close together along the inner side of the mantle, two straight main ovarian ducts run upwards for a short distance and bend obliquely downwards where the mantle is connected 
with the body proper, and then pass separately within the prosoma to the external openings on the ventral side.

In a fully matured female, the ovaries (Figs. 34 and $35 \mathrm{~B}$ ) are greatly massive, filling up the interior of the mantle underlying the disc, and thus the ovarian

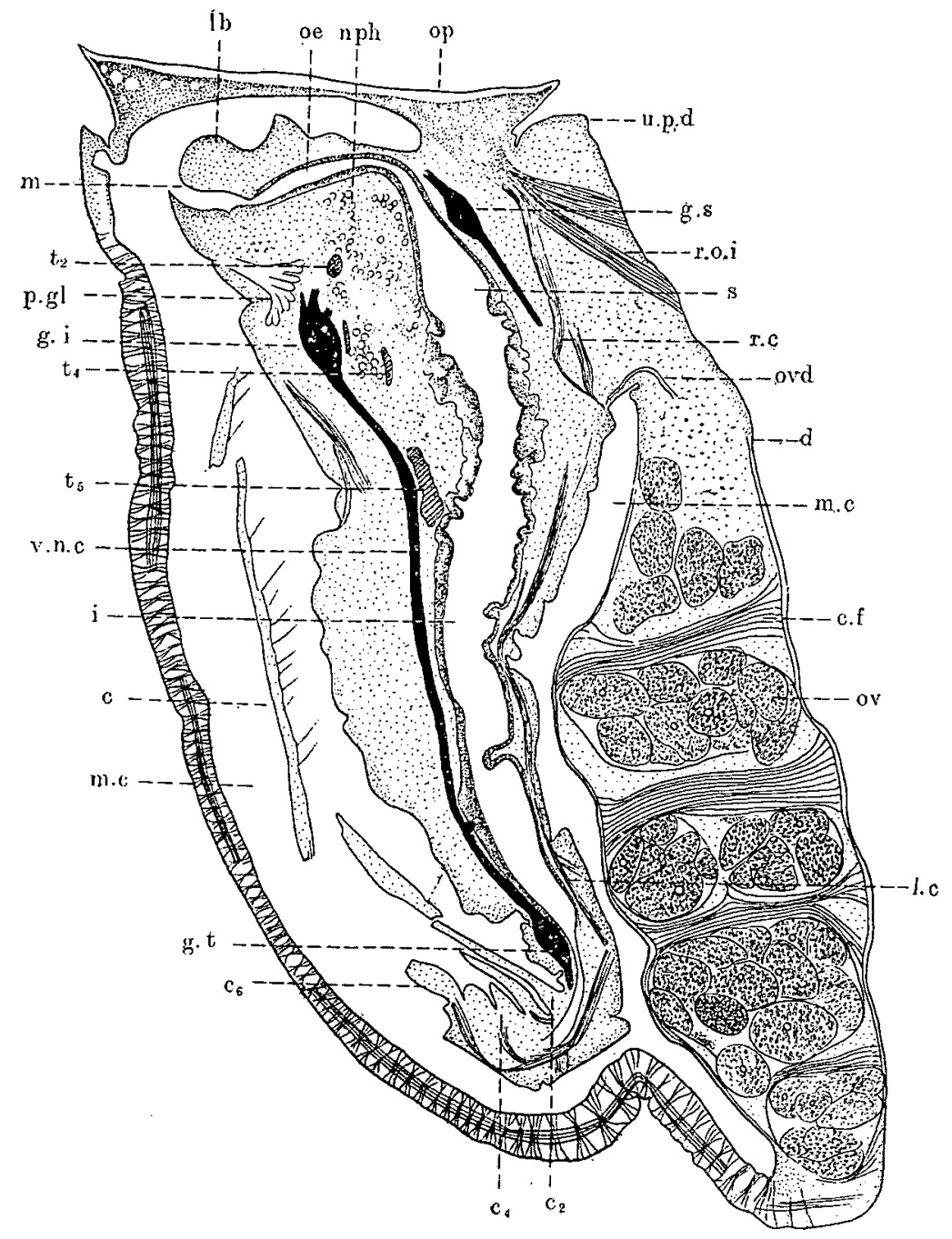

Fig. 34. Median longitudinal section a full-grown female. Lettering as on p. 278 . $[\times 34]$

tubes become so obscure that cannot be traced. The ovaries are formed of 5 or 6 large masses piled up to one another, separating by strongly developed horizontal layers of connective tissue fibres ( $c . f$ ); each mass contains a number of welldeveloped ova, surrounded by the tunica propria $(t . p)$ and a thin fibrous layer 
of connective tissue. Such a formation of outer covering around the ovaries is not always the case, since it differs in appearance with age or development of ovaries.

The two main oviducts originate near the apex of the ovaries and proceed alongside the alimentary canal and below the fifth transverse muscle, and then bend suddenly downwards near the ventrolateral surface of the body. A little before opening to the exterior, the duct becomes gradually wider and forms a broad elongated cavity called as the atrium (Fig. $36 \mathrm{~A}-\mathrm{B}$, at).

In transverse sections, the atrium is seemingly composed of a spindle-shaped cavity with thickened wall, lengthened parallel to the external surface. The vagina

A

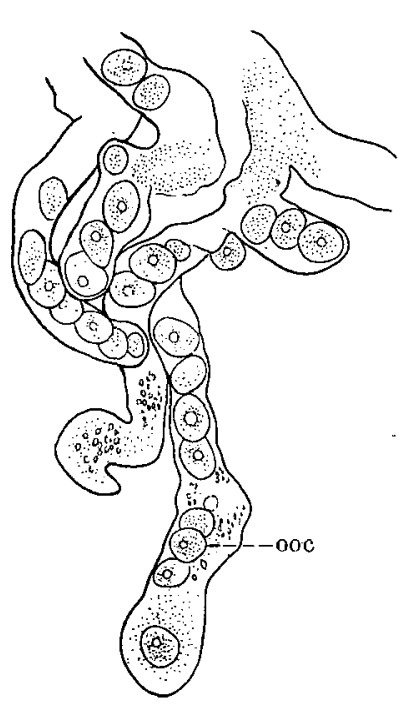

B

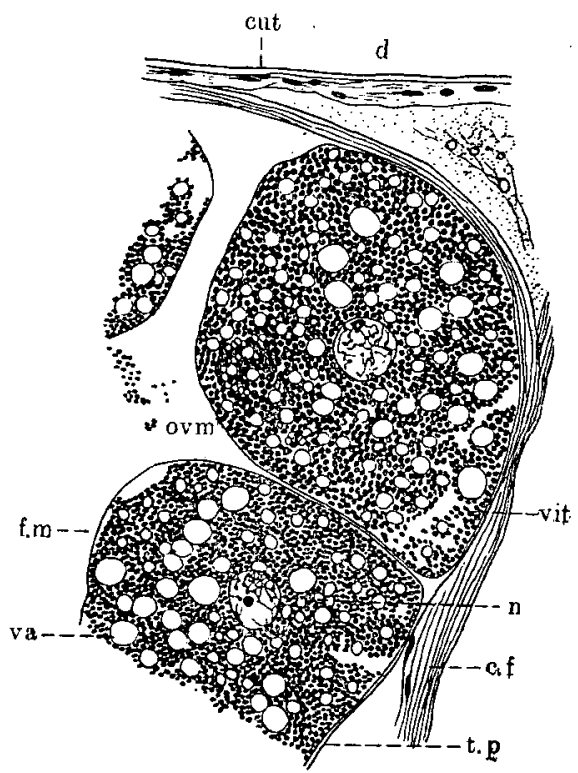

Fig. 35. A, ovary in young female. B, part of ovary in full.grown female. Lettering as on p. 278 . (A, $\times 55 ; \mathrm{B}, \times 210)$

$(v g)$ continued from the terminal end of the atrium bends backwards abruptly and gradually enlarges towards the external opening (g.o). This genital opening lies below a slight swelling at the base of the mouth-cirrus as an extremely small split, so that it may be hardly distinguishable by mere superficial examination.

The fertilized ova, when excluded, are contained in the mantle cavity where they are retained until hatching takes place. They are numerous and form two concave, nearly circular, lamellae. These lamellae lie low down freely within the mantle cavity under the body. No other structure recalling of the so-called 'ovigerous fraena' or branchiae is found. 
Histology. The internal structure of the ovary shows little difference from that found in other acrothoracicans. When the ovary is mature or nearly so, the developing ova are generally rounded oval and crowded so close together that they come to assume an almost polygonal shape compressed through mutual pressure.

All these ova (ovm) are enclosed together by a thin layer of the tunica propria (Fig. 35B,t.p). In somewhat less-developed ovaries, they do not fill the interior of the ovarian caeca, but a proliferating zone of egg-cells, the so-called 'Reimlager', is inserted between mature eggs. Such cell-cluster is generally situated close to the tunica propria and shows a coarsely granulated mass of
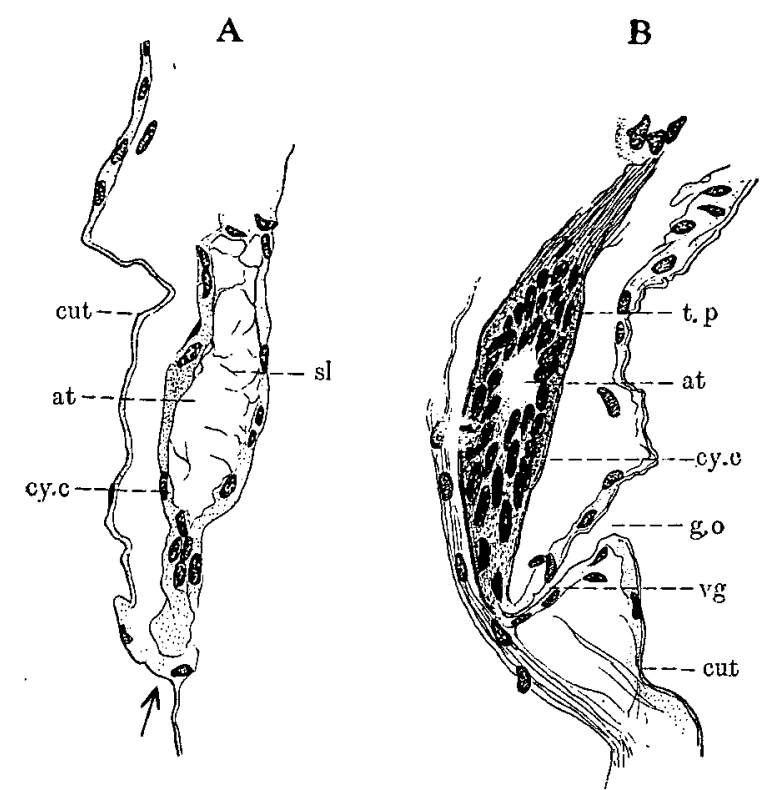

Fig. 36. A, longitudinal section of atrium. B, the same with genital opening in another specimen. Lettering as on p. 278 . [All $\times 560]$

plasm with many chromatic granules. A fully matured ovum measures about $0.16 \mathrm{~mm} \times 0.22 \mathrm{~mm}$ which size is somewhat smaller than that of the egg of Trypetesa lampas $(0.25 \mathrm{~mm} \times 0.34 \mathrm{~mm}$ after BERNDT).

The nucleus $(n)$ is round, about $0.03 \mathrm{~mm}$ in diameter and contains a conspicuous nucleolus, about $5 \mu$ in diameter. The cytoplasm is filled with a great deal of coarsely granulated, eosinophilous vitelline mass (vit) and transparent vacuoles (va) varying in size from $5 \mu$ to $15 \mu$. The wall consists of a very thin, structureless follicle membrane $(f . m)$. The younger ovum or oocyte (Fig. $35 \mathrm{~A}, o o c$ ) is about $0.08 \mathrm{~mm}$ in diameter and shows a nearly similar but more primitive structure. 
The wall of the atrium is thickened and formed of cylindrical epithelial cells (Fig. 36, cy.c) which contain a very large oval nucleus basally, about $6-7 \mu$ in longest diameter; sometimes they are not so high and slimy threads $(s l)$ are found on their inner surface.

\section{Circulatory and Respiratory System}

Since-the classical work of- DARwIN $(-1851,1854)$; it has been generally recognized that in the Cirripedia there are no special organs of circulation but the circulation is lacunar, the body being permeated by vessels without any real walls. DARwIN did not comment himself as to how the blood circulates round the body, but subsequent workers state that the body movements are responsible for the circulation. According to the detailed investigation by CANNON (1947) for the pedunculate cirriped Lithotrya, however, it seems very probable that the motive power for the circulation of blood relies solely on the normal rhythmical movement of the cirri. He further emphasizes that there is no real heart but there is a structure called as 'blood pump' between the oral cone and the adductor scutorum muscle which by its contraction forces the blood around the body through blood vessels rather than lacunae.

Although I could not enter into such a speculation in this acrothoracican, it seems to be reasonable to consider that the blood system is mainly canalicular rather than lacunar as he suggests. As described above, blood lacunae are found almost everywhere among the tissues, especially in the area of the large muscles, the mantle and its derivatives like the operculum.

In this connection it should be mentioned that there are a number of large cell-masses called as 'nephrocytes' free within the large lacunae around the digestive glands in the cephalic region, where the blood may pass through the lacunar connective tissues without definite vessels (See pp. 242-244). Further the flexible 'conical processes' situated on the ventrolateral sides of the body may be looked upon as a structure concerned with the respiration like the filamentary appendages found in the cryptophialids and some of ordinary pedunculate cirripeds, for they are apparently structureless but lacunar and empty in the interior.

\section{Summary}

1. The results of my investigations on the detailed internal anatomy and histology of the female of Berntia purpurea UTINOMI are here presented.

2. The alimentary canal is of the same type as in ordinary cirripeds. It differs principally by the presence of a pair of large digestive glands from other known acrothoracicans.

3. The 'poison' or 'salivary' gland and an enigmatic eosinophilous body are discussed. The so-called 'cement gland' does not exist in the adult. 
4. As the excretory organs, the typical maxillary glands and the peculiar cephalic nephrocytes are present. The latter, which are unknown in other acrothoracicans, are supposed to be the special cell-masses in which waste products are temporarily stored in connection with the blood circulation.

5. The nervous system is more complicated than in any other acrothoracicans, apparently representing a somewhat intermediate feature between the pedunculate and sessile groups of ordinary cirripeds. In particular, the presence of a pair of highly developed eyes is noticeable for the group of Acrothoracica.

6. The muscular system is more developed than in any other acrothoracicans, and peculiar in the presence of powerful retractor muscles of the operculum. In the body there are 8 transverse muscles connecting the body walls of both sides; of these the first one is not homologous with the 'adductor scutorum' muscle of ordinary cirripeds.

7. The reproductive organs do not much differ from those of ordinary cirripeds.

8. There are no special organs of circulation. But blood lacunae are found almost everywhere among the tissues. The flexible body process such as the conical processes (in Berndtia and Lithoglyptes) and filamentary appendages (in Cryptophialus) located ventrally or dorsally may serve to help the respiration like the ordinary gills.

\section{REFERENCES}

Aurivillius, C. W. S. 1894. Studien über Cirripeden. Kungl. Sv. Vetensk. Akad. Handl., Bd. 26, no. 7, pp. 1-107.

Berndt, W. 1903a. Zur Biologie und Anatomie von Alcippe lampas Hancock. Inaug. Diss., Univ. Berlin (1902) ; Zeitsch. wiss. Zool., Bd. 74, Ht. 3, pp. 396-457.

1903b. Die Anatomie von Cryptophialus striatus Berndt. Sitzber. Ges. naturf. Fr. Berlin, 1903, Nr. 10, pp. 436-444.

1907. Studien an bohrenden Cirripedien (Ordnung Acrothoracica Gruvel, Abdo. minalia Darwin). I. Teil : Die Cryptophialidae. Arch. Biontol., Bd. 1, pp. 167-210.

BRATTSTRÖM, H. 1956. On the organization of the genus Baccalaureus (Ascothoracica) with description of a new South African species. In: Bertil Hanström, Zool. Papers in honour of his 65 th birthday (Edited by K. G. Wingstrand), pp. 106-119. Lund.

BrinkmanN, A. 1936. Die nordischen Munida.Arten und ihre Rhizocephalen. Bergens Mus. Skrifter, Nr. 18, pp. 1-111.

BrocH, Hj. 1919. Anatomical studies on Anelasma and Scalpellum. Norske Vidensk. Selsk. Skr., 1918, Nr. 1, pp. 1-28.

Bruntz, L. 1902. L'excrétion chez les Cirripèdes. C. R. Acad. Sci. Paris, Tom. 135, pp. 987-988. 1904. Contribution à l'étude de l'excrétion chez les Arthropodes. Arch. de Biol., Tom. 20, pp. 217-422.

Burian, R. 1924. Die Exkretion (Crustaceen). In: Handbuch der vergleichende Physiol., Herausgegb. von $\mathrm{H}$. Winterstein), Bd. 2, pp. 633-695.

Cannon, H. G. 1947. On the anatomy of the pedunculate barnacle Lithotrya. Phil. Trans. Roy. Soc. London, Ser. B, Biol. Sci., Vol. 233, no. 595, pp. 89-136. 
DARWIN, Ch. 1851. A monograph on the sub-class Cirripedia. The Lepadidae. 400 pp., 10 pls. London.

1854. A monograph on the sub-class Cirripedia. The Balanidae, the Verrucidae, etc. 684 pp., 30 pls. London.

Defner, A. 1910. Der Bau der Maxillardrüse bei Cirripedien. Arb. Zool. Inst. Wien, Tom. 18, Ht. 3, pp. 183-206.

FALES, D. E. 1928. The light-receptive organs of certain barnacles. Biol. Bull., Vol. 54, No. 6, pp. $534-547$.

Genthe, K. W. 1905. Some notes on Alcippe lampas (Hanc.) and its occurrence on the American Atlantic shore. Zool. Jahrb., Abt. Anat., Bd. 21, Ht. 2, pp. 181-200.

Gruvel, A. 1893. Contributions à l'étude des Cirrhipèdes. Arch. Zool. exp. gén., (3), Tom. 1, pp. 401-610.

1904. Revision des Cirrhipèdes appartenant à la collection du Muséum d'histoire naturelle. Cirrhipèdes thoraciques II. Partie anatomique. Nouv. Arch. Mus. Hist. nat. Paris, (4), Tom. 6, pp. 51-224.

1905. Monographie des Cirrhipèdes ou Thécostracés. 472 pp., Paris.

HoEk, P. P. C. 1884. Report on the Cirripedia collected by H. M. S. Challenger during the years 1873-76. Anatomical part. Rep. Sci. Res. Challenger, Zool., Vol. 10. 47 pp., 6 pls. London.

HoffendahL, K. 1904. Beitrag zur Entwicklungsgeschichte und Anatomie von Poecilasma aurantium Darw. Zool. Jahrb., Abt. Anat., Bd. 20, Ht. 1, pp. 1-39.

Johnstone, J. \& Frost, W. E. 1927. Anelasma squalicola (Lovén), its general morphology. Rep. Lancashire Sea-Fish. Lab., Vol. 35. (Not seen.)

KNIPOWITSCH, N. 1892. Beiträge zur Kenntnis der Gruppe Ascothoracida. Trav. Soc. Natural. St.-Pétersb., Tom. 23, Livr. 2, pp. 1-155. (In Russian with German résumé.)

KOEHLER, R. 1892. Recherches sur la cavité générale et l'appareil excréteur des Cirrhipèdes. C. R. Acad. Sci. Paris, Tom. 114, pp. 1214-1217.

KRƯGER, P. 1940. Cirripedia und Ascothoracida. Bronn's Klassen und Ordnungen des Tierreichs, Bd. 5, Abt. 1, Buch 3, Teil 3. 560 pp.; Teil 4. 46 pp. Leipzig.

KÜHNERT, L. 1934. Beitrag zur Entwicklungsgeschichte von Alcippe lampas Hancock. Zeit. Morph. Ökol., Bd. 29, Ht. 1, pp. 45-78.

Nilsson-Cantell, C.-A. 1921. Cirripeden-Studien. Zur Kenntnis der Biologie, Anatomie und Systematik dieser Gruppe. Zool. Bidr. Uppsala, Bd. 7, pp. 75-390.

1934. Indo-Malayan cirripeds in the Raffles Museum, Singapore. Bull.

Raffles Mus. Singapore, No. 9, pp. 42-73.

Nussbaum, M. 1890. Anatomische Studien an Californischen Cirripedien. 97 pp., 12 pls. Bonn.

Pyefinch, K. A. 1934. Baccalaureus maldivensis, a new species of ascothoracican. Q. J. Micr. Sci., Vol. 77, pt. 2, pp. 223-242.

1936. The internal anatomy of Baccalaureus, with a description of a new species. Ibid., Vol. 78 , pt. 5, pp. 653-686.

1937. The anatomy of Baccalaureus torrensis, sp. n. (Cirripedia Ascothoracica). Journ. Linn. Soc. Lond., Zool., Vol. 40, No. 272, pp. 347-371.

SEWELL, R. B. S. 1926. A study of Lithotrya nicobarica Reinhardt. Rec. Ind. Mus., Vol. 28, Pt. 4, pp. 269-330.

STEWART, F. H. 1911. Studies in post-larval development and minute anatomy in the genera Scalpellum and Ibla. Mem. Ind. Mus., Vol. 3, pp. 33-51.

TOMLinson, J. T. 1953. A burrowing barnacle of the genus Trypetesa (order Acrothoracica). Journ. Wash. Acad. Sci., Vol. 43, No. 11, pp. 373-381.

1955. The morphology of an acrothoracican barnacle, Trypetesa lateralis. Journ. Morph., Vol. 96, No. 1, pp. 97-121.

1960. Cryptophialus coronatus, a new species of acrothoracican barnacle from

Dakar. Bull. de I'I. F. A. N., Sér. A, Tome 22, No. 2, pp. 402-410. 
TöRnävä, S. R. 1948. The alimentary canal of Balanus improvisus Darwin. Acta Zool. Fenn., 52 , pp. 1-52.

UTINOMI, H. 1950a. A new remarkable coral-inhabiting acrothoracican cirriped. Mem. Coll. Sci. Univ. Kyoto, Ser. B. Vol. 19, no. 3, pp. 83-89.

1950b. General account of the Acrothoracica. In : Some problems of modern biology (Edited by K. Nakamura), pp. 428-461. Osaka. (In Japanese.)

1957. Studies on the Cirripedia Acrothoracica. I. Biology and external morphology 


\section{EXPLANATION OF PLATES XXXI-XXXIII}

Transverse sections of a female specimen of Berndtia purpurea UTINOMI. (red color-muscles, blue-nerves and ganglia, yellow-excretory cells and nephrocytes.) All $\times 82$.

\section{Plate XXXI}

Fig. 1. Section passing through the first transverse muscle in the upper region of the head.

Fig. 2. Section passing a little below the first transverse muscle, showing the enigmatic eosinophilous bodies.

Fig. 3. Section passing through the second transverse muscle in the middle region of the head.

Fig. 4. Section passing through the region just below the mouth, showing the maxillary and poison glands.

\section{Plate XXXII}

Fig. 5. Section passing through the infra-oesophageal ganglion below the mouth.

Fig. 6. Section passing through the third and fourth transverse muscles, showing the digestive glands.

Fig. 7. Section passing through the proximal region of the intestine.

Fig. 8. Section passing through the fifth transverse muscle.

\section{Plate XXXIII}

Fig. 9. Section passing through the genital openings.

Fig. 10. Section passing through the middle region of the intestine, showing the offshoots of a paired tegumentary nerve.

Fig. 11. Section passing through the terminal ganglion.

Fig. 12. Section passing through the constricted region of the body near the terminal end. (The mantle is removed.) 
List of Abbreviations used in the Figures in the Text and Plate

\begin{tabular}{|c|c|c|c|}
\hline $\begin{array}{l}\text { a.c.i } \\
\text { a.c.s }\end{array}$ & $\begin{array}{l}\text { Adductor capitis inferior. } \\
\text { Adductor capitis supperior. }\end{array}$ & f.c & $\begin{array}{l}\text { Flexor corporis (retrahens \& attrahens } \\
\text { ventralis). }\end{array}$ \\
\hline a.1 & Attrahens lateralis. & f.c.l & Flexor cirri lateralis. \\
\hline a.md & Adductor mandiblae. & f.c.m & Flexor cirri medialis. \\
\hline a. $m x_{1}$ & Adductor maxillae I. & f.m & Follicle membrane of ovum. \\
\hline a. $m x_{2}$ & Adductor maxillae II. & f. $\mathrm{mx}_{1}$ & Flexor maxillae I. \\
\hline a.p & Adductor pedis I. & $\mathrm{f} \cdot \mathrm{mx}_{2}$ & Flexor maxillae II. \\
\hline a.pr & $\begin{array}{l}\text { Attachment-process (Upper knob of } \\
\text { the attachment-disc). }\end{array}$ & $\begin{array}{l}\text { fl } \\
\text { fl.c }\end{array}$ & $\begin{array}{l}\text { Funnel-like communication. } \\
\text { Funnel cell. }\end{array}$ \\
\hline a. $v_{1-2}$ & Attrahens ventralis I-II. & g.c & Ganglionic cell. \\
\hline at & Atrium & g.i & Infra-oesophageal ganglion. \\
\hline b & Body & g.s & Supra-oesophageal ganglion. \\
\hline b.m & Basal membrane. & g.t & Terminal ganglion. \\
\hline $\mathrm{C}$ & Carinal (ventral) side. & $\mathbf{H}$ & Head. \\
\hline$c_{1-6}$ & Cirri I-VI. & i & Intestine. \\
\hline c.b.m & $\begin{array}{l}\text { Connective line between the body and } \\
\text { mantle. }\end{array}$ & $\begin{array}{l}\text { i.c.e } \\
l_{1-3}\end{array}$ & $\begin{array}{l}\text { Inner covering of eye. } \\
\text { Longissimus corporis I-III. }\end{array}$ \\
\hline c.c & Comb-collar. & 1.b & Lateral bar. \\
\hline c.f & Connective tissue fibre. & 1.c & Longissimus corporis. \\
\hline c.i & Constricted portion of intestine. & $1 . d$ & Longissimus corporis dorsalis. \\
\hline c.p & Connective parts. & $1 . \mathbf{i}$ & Longissimus corporis intermedius. \\
\hline c.t & Connective tissue. & 1.1 & Lower lobe. \\
\hline cor.c & Cortical cell. & l.m & Longitudinal muscle of mantle. \\
\hline $\mathrm{cr}$ & Crest-like projection. & lac & Lacunae. \\
\hline cut & Cuticle. & lac.o & Lacunae of operculum. \\
\hline cut.e & External cuticular layer of mantle. & lb & Labrum. \\
\hline cut.i & Internal cuticular layer of mantle. & lv.c & Levator capitis. \\
\hline cy.c & Cylindrical epithelial cell of atrium. & lv.md & Levator mandiblae. \\
\hline $\mathrm{D}$ & Dorsal (rostral) side. & lv. $\mathrm{mx}_{1}$ & Levator maxillae I. \\
\hline d & Attachment-disc. & $\operatorname{lv} . \mathrm{mx}_{2}$ & Levator maxillae II. \\
\hline d.c & Depressor capitis. & $\mathrm{m}$ & Mouth. \\
\hline d.gl & Digestive gland. & m.c & Mantle cavity. \\
\hline d.md & Depressor mandiblae. & $\mathrm{m} . \mathrm{f}$ & Mesenterial filament. \\
\hline $\mathrm{d} \cdot \mathrm{mx}_{1}$ & Depressor maxillae I. & md & Mandible. \\
\hline d. $m x_{2}$ & Depressor maxillae II. & $\mathrm{mp}$ & Mandibular palp. \\
\hline d.n.c & Dorsal nerve cord. & $\mathrm{mx}_{1}$ & Maxilla I. \\
\hline d.oe.i & Dilatator oesophagi inferior. & $\mathrm{mx}_{2}$ & Maxilla II. \\
\hline d.oe.s & Dilatator oesophagi superior. & $\mathrm{mx} \cdot \mathrm{g}$ & Maxillary gland. \\
\hline e & Eye. & mx.s & Maxillar stalk or apodeme. \\
\hline e.b & Eosinophilous body. & $\mathrm{n}$ & Nucleus. \\
\hline e.f & Elastic fibre. & n.ad & Adductor nerve. \\
\hline e.i & Extensor intermedius. & n.bu & Buccal nerve. \\
\hline end & Endosac. & n.c & Cirral (or pedal) nerve. \\
\hline ep.c & Epithelial cell. & n.c.f & Nucleus of connective tissue fibre. \\
\hline ex.c & Excretory cell of endosac. & n.c.t & Free nucleus in connective tissue: \\
\hline ex.g & Excrete globule. & n.d & Dorsal nerve. \\
\hline ex.o & Excretory opening. & n.int & Intestinal nerve. \\
\hline f.b.p & Flexor baseos pedis. & n.lat & Lateral nerve. \\
\hline
\end{tabular}




\begin{tabular}{|c|c|c|c|}
\hline n.oes & Oesophageal nerve. & r.cut & Remains of old cuticular coverings. \\
\hline n.op & Optic nerve. & r.e.f & Radial elastic fibre. \\
\hline n.or & Orificial nerve (adductor nerve). & r.1 & Retrahens lateralis. \\
\hline n.n & Peduncular (antennular) nerve. & r.m & Ring muscle of oesophagus. \\
\hline n.pal & Pallial nerve. & r.o & Rector orificii. \\
\hline n.teg & Tegumentary nerve. & r.o.i & Retractor orificii inferior. \\
\hline n.vis & Visceral nerve. & r.o.s & Retractor orificii superior. \\
\hline & Neurilemm. & r. $p_{1-4}$ & Retractor pedis I-IV. \\
\hline & Neuropile. & r.r & Retractor pallii rostralis. \\
\hline nph & Nephrocytes. & r. $v_{1-2}$ & Retrahens ventralis I-II. \\
\hline o.c.e & Outer covering of eye. & s & Stomach. \\
\hline o.d & Oil drop. & sh & Outer sheath of nerve cord. \\
\hline o.m & Oblique muscle of mantle. & sl & Slimy thread. \\
\hline oe & Oesophagus. & st.s & Striped structure of intestinal cells. \\
\hline oe.c & Oesophageal commissure. & $t_{1-8}$ & Transversalis I-VIII. \\
\hline ooc & Oocyte. & t.m & Transverse muscle of mantle. \\
\hline op & Oṕerculum. & t.p & Tunica propria. \\
\hline or & Orifice. & t.s.m & Inner transverse muscle for support. \\
\hline ov & Ovary. & & ing mantle-sac. \\
\hline ovd & Oviduct. & u.1 & Upper lobe. \\
\hline ovm & Ovum. & u.p.d & Upper projection (knob) of sttach- \\
\hline p & Proctodaeum. & & ment-disc. \\
\hline p.c & Protractor corporis. & ur.d & Urinary duct. \\
\hline p.gl & Poison gland. & $\mathrm{V}$ & Ventral (carinal) side. \\
\hline $\mathbf{R}$ & Rostral (dorsal) side. & v.c & Visual cell. \\
\hline r.c & Retractor corporis. & v.n.c & Ventral nerve cord. \\
\hline r.c.a & Retractor corporis anterior. & va & Vacuole. \\
\hline r.c.i & Retractor corporis intermedius. & $\mathrm{vg}$ & Vagina. \\
\hline r.c.p & Retractor corporis posterior. & vit & Vittelline mass. \\
\hline
\end{tabular}


Publ. Seto Mar. Biol. Lab., VIII, 2 (1960)
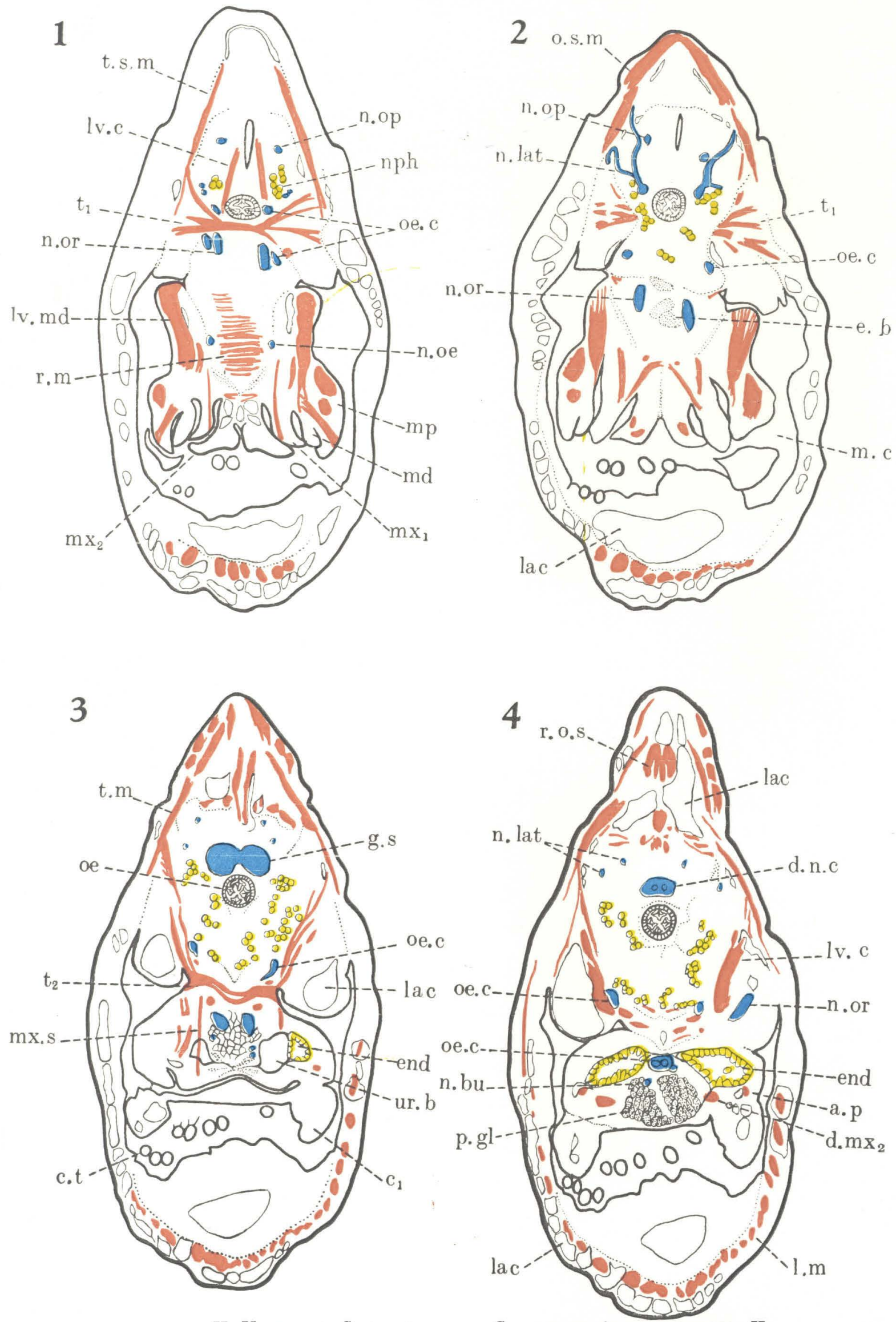

H. Utinomi: Studies on the Cirripedia Acrothoracica, II. 
Publ. Seto Mar. Biol. Lab., VIII, 2 (1960)

PLATE XXXIII

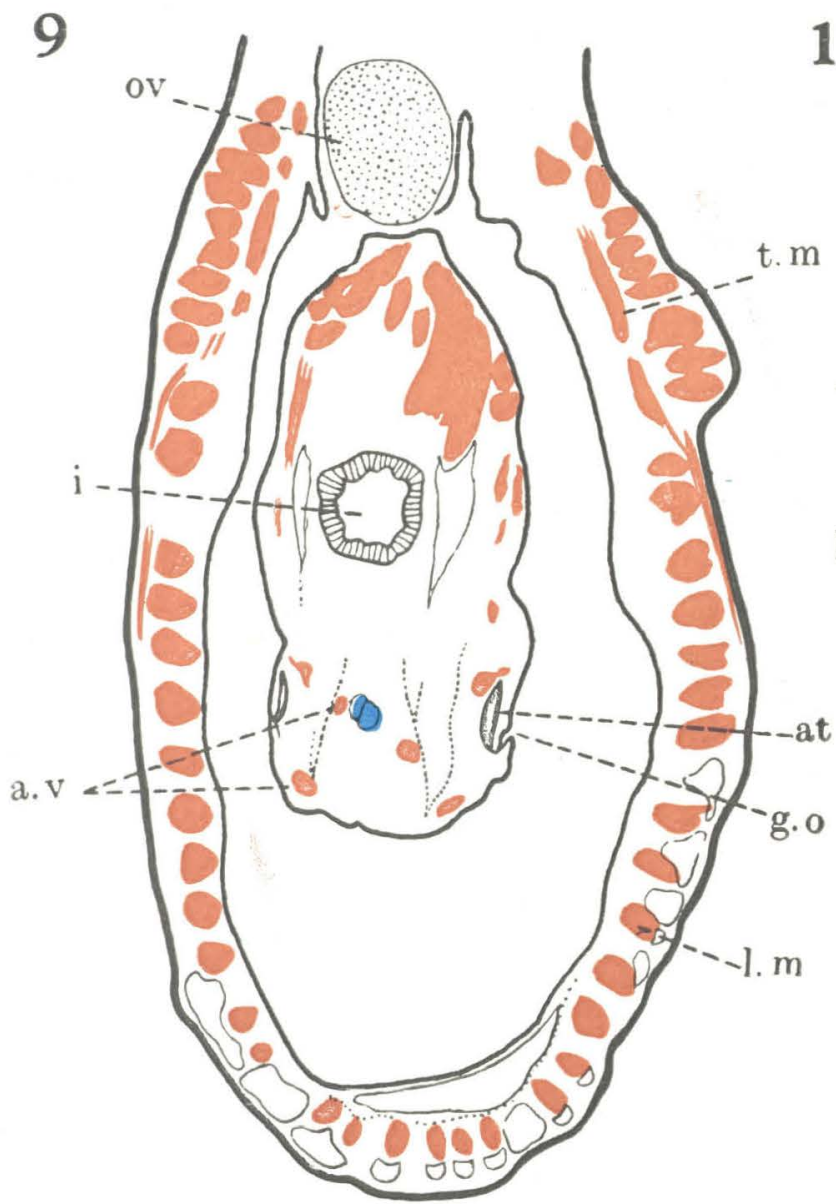

10

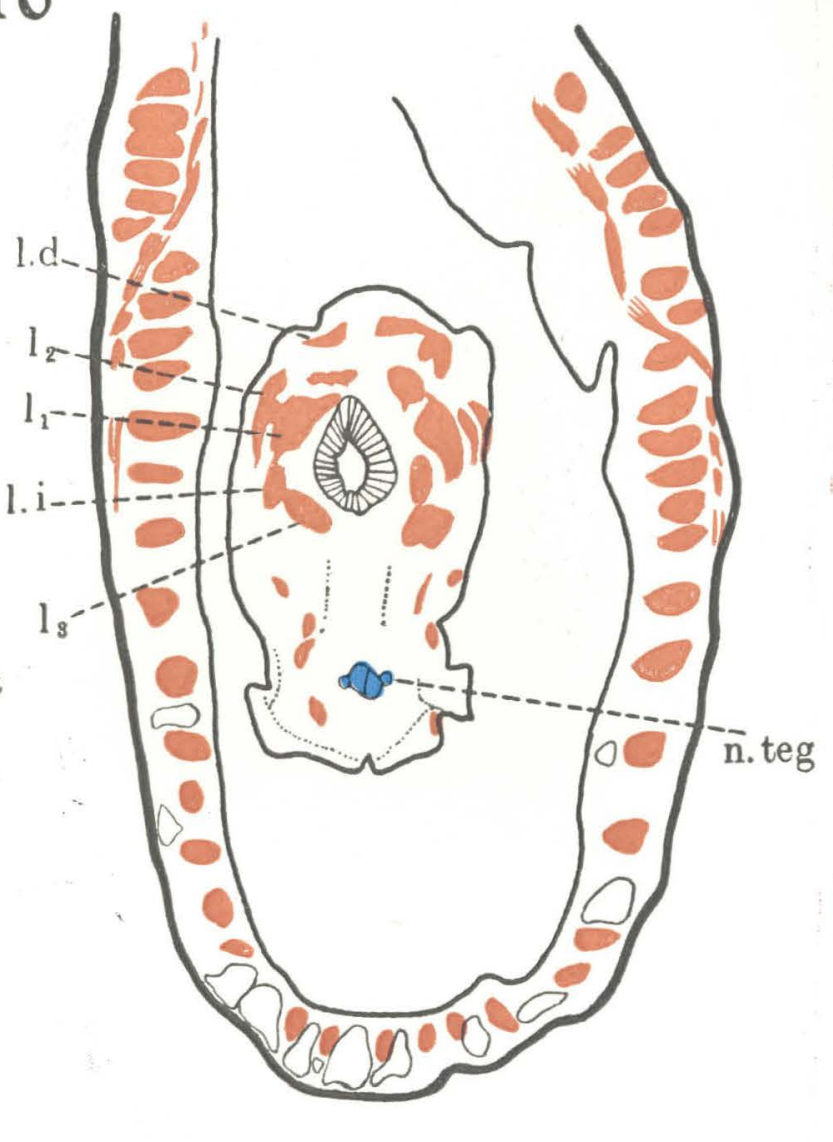

11
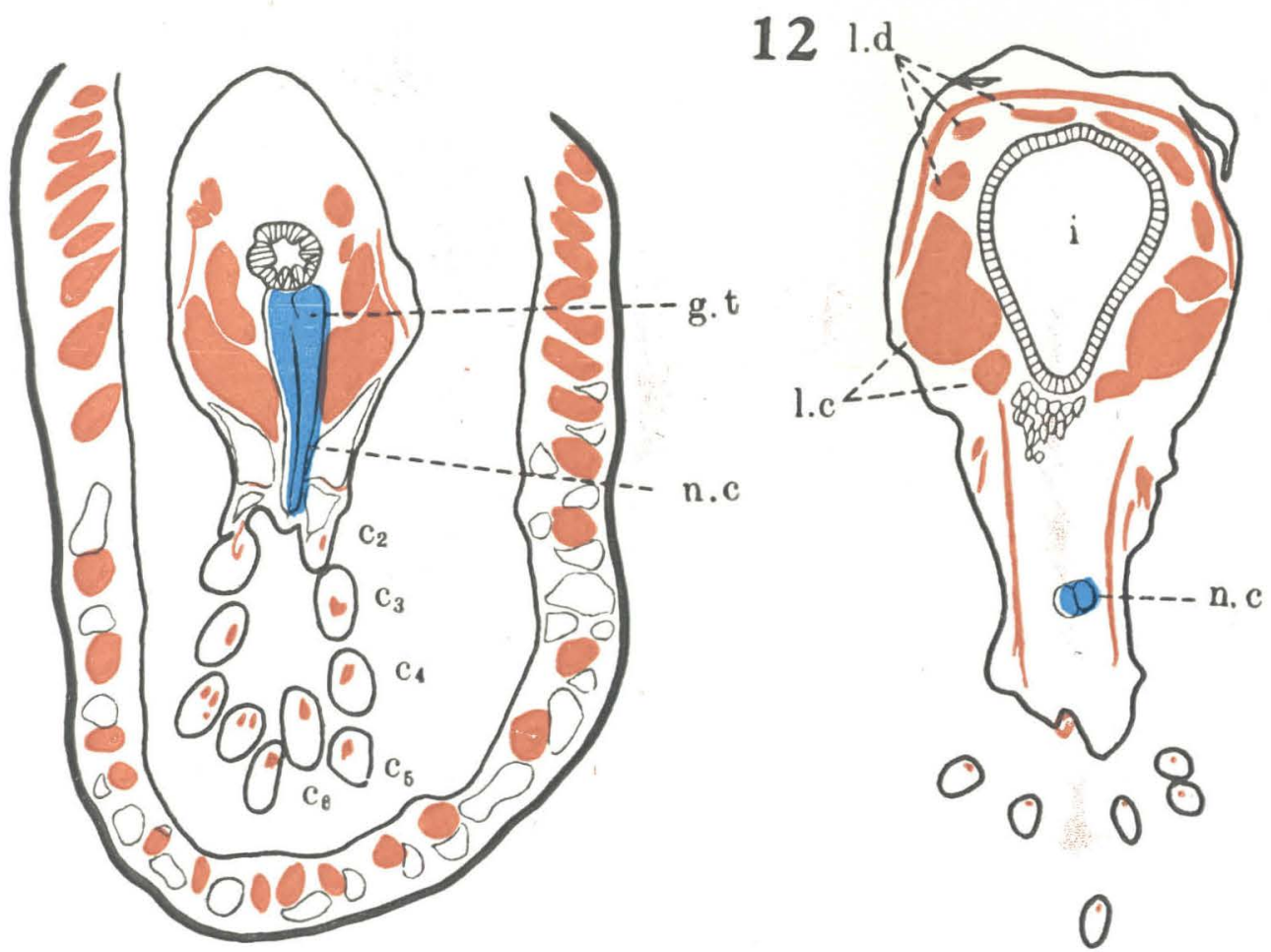

H. Utinomi: Studies on the Cirripedia Acrothoracica, II. 